Review

\title{
Hydrogen Industry: A Technical, Economic, and Market Analy- sis Overview
}

\author{
Nima Norouzi ${ }^{D}$, Maryam Fani *
}

How to cite this paper : Norouzi, N., \& Fani, M. (2021). Hydrogen Industry: A Technical, Economic, and Market Anal-ysis Overview. Online Journal of Chemistry, 1(1), 59-84. Retrieved from https://www.scipublications.com/journal/index.php/ojc/article/view/106

Received: August 12, 2021 Accepted: September 23, 2021 Published: September 24, 2021

Copyright: (c) 2021 by the authors. Submitted for possible open access publication under the terms and conditions of the Creative Commons Attribution (CC BY) license (http://creativecommons.org/licenses /by/4.0/).
Department of energy engineering and physics, Amirkabir university of technology (Tehran polytechnic), 424 Hafez Avenue, PO. Box 15875-4413, Tehran, Iran

*Correspondence: mfani@aut.ac.ir;

\begin{abstract}
Like electricity, hydrogen is an excellent energy carrier, as it can be produced from many different and abundant precursors, such as natural gas, coal, water, and renewable energy. The use of hydrogen in fuel cells, particularly in the transport sector, will make it possible to diversify the energy supply, take advantage of domestic resources, and reduce oil imports dependence. Unlike other fuels, hydrogen $\left(\mathrm{H}_{2}\right)$ can be generated and consumed without emitting carbon dioxide $\left(\mathrm{CO}_{2}\right)$. This results in great ecological benefits and fundamental challenges. Hydrogen can operate in a closed and inexhaustible cycle based on the cleanest, most abundant, and elemental substances: water, oxygen, and hydrogen. If hydrogen is generated using light, heat, and electricity produced from solar, wind, or nuclear energy, hydrogen becomes a versatile and universal means of storing and transporting energy and a necessary element for future energy systems that operate without environmental pollution, $\mathrm{CO}_{2}$, and other gases that contribute to the greenhouse effect. Hydrogen is necessary to eliminate environmental pollution and stabilize the composition of the planet's atmosphere and climate. This paper investigates different methods of hydrogen production in the term of their technological and economic aspects. This paper shows that thermochemical methods dominate the hydrogen market while emerging electroreduction methods are developing fast, which might turn the tide in the future.
\end{abstract}

Keywords: Hydrogen Economy, Hydrogen market, electrochemical method, thermochemical method, solar fuel

\section{Introduction}

Hydrogen $\left(\mathrm{H}_{2}\right)$ is considered the most attractive energy for the near future because its combustion is not polluting. When combined with oxygen in the air, hydrogen releases the chemical energy stored in the $\mathrm{H}-\mathrm{H}$ bond, generating only water vapor as a combustion product. It can be stored as a gas under pressure and as a liquid or distributed through gas pipelines, so it is considered that it can replace natural gas in the medium-long term $[1,2]$.

Since no greenhouse gases are produced during its combustion, hydrogen offers great potential to reduce the $\mathrm{CO}_{2}$ emissions generated during its fossil-based precursors' combustion. Hydrogen is practically not in a free state on Earth, so it is not primary energy. However, it can be produced from different precursors by chemical or biochemical processes [3].

The chemical industry for ammonia, methanol, and petroleum refining consumes approximately $66 \%$ of the annual $\mathrm{H}_{2}$ production, estimated at 35 million metric tons. The rest of the production is consumed in other industrial processes. Hydrogen is considered an ideal fuel since it does not emit greenhouse gases during combustion. This appeal is even greater when used in fuel cells. These devices convert the chemical energy stored in the $\mathrm{H}-\mathrm{H}$ bond into electrical energy through a process not subjected to the Carnot cycle. 
For this reason, the energy efficiency is two to three times higher than that of a heat engine. Based on these arguments, there is no doubt about the importance of hydrogen in developed countries' energy schemes on a medium and long-term scale. Large-scale hydrogen production will not only alleviate dependence on oil, but will also reduce environmental pollution when fuel cells are incorporated in both automotive and stationary applications [4].

The concept of the "Hydrogen Economy" has been around for many years. Jules Verne was the first to propose an economy based on hydrogen in his novel "The Mysterious Island" in 1874 [5]. The concept has evolved as humanity has transformed its energy infrastructure. Initially, coal or nuclear energy could be used to produce hydrogen on a large scale. Recent advances in renewable energy (solar and wind) make hydrogen produced from these energy sources [6-10]. The hydrogen economy is based on technologies that have been around for many years. Electrolyzers and fuel cells were invented in the 19th century before the internal combustion engine was invented and petroleum was discovered. Other important technologies for the use of hydrogen were developed during the space program in the 1960s. Later, interest in hydrogen as a fuel for transportation resurfaced due to the oil crises of the 1970s. Since then, many hydrogen-powered cars have been built, and hydrogen production, storage, and utilization technologies have been investigated [7].

Recently, the interest in hydrogen has increased considerably. In the United States, President Bush announced in 2003 a program that targets large-scale hydrogen car production by 2020. California Governor Arnold Schwarzenegger introduced a plan to build 200 hydrogen vehicle service stations toward the year 2010. Interest in this technology has spread to Asia and Europe, and the case of Iceland is very notable, which has proposed eliminating its consumption of fossil fuels and replacing them with hydrogen by 2030 . The renewed interest in hydrogen has resulted in new studies [8,9], enthusiasm [10], doubts [11], and criticism, some of which come from renowned experts in the field of energy[12].

We believe that it is possible to respond appropriately to all these criticisms. As well as that, the hydrogen economy is not only justified; it is an urgent necessity. Hence, the need to accept and promote the hydrogen economy must be recognized. This will allow starting the difficult work of converting the economy to hydrogen optimally, minimizes implementation costs, and dedicates the appropriate resources to develop the necessary technologies [13].

This article first investigates each hydrogen generation method's technical aspects and then answers the hydrogen economy's most common criticisms. We also present the technical challenges that must be solved for the hydrogen economy to become a reality. The article concludes by describing four models that can be followed to implement the hydrogen economy[14].

\section{Hydrogen production methods}

Hydrogen fuel infrastructure can be designed in a variety of ways. Experts believe that hydrogen production sources and transportation and distribution will vary according to geographical conditions and benefits. For example, in areas where cheap natural gas resources are available, hydrogen production from gas sources is the most cost-effective method. In an area where cheap electricity is available, hydrogen production from electricity sources by water electrolysis is justified economically. In areas where other fuels such as ethanol are present, ethanol has a special advantage as the primary source of hydrogen. Hydrogen production and distribution methods include:

- Centralized hydrogen production

- Distribution as liquid hydrogen

- Distribution as compressed gas

- Solid distribution (gas stored in metal hydrides) 
- Production of hydrogen gas in refueling stations (decentralized)

- From natural gas sources by methane reforming and partial oxidation

- By alkaline electrolysis of water

- By electrolysis with polymer membranes

- Hydrogen gas production on the car

- Using gasoline or diesel as fuel and converting it to hydrogen in the car converter

- Use methanol or any other suitable liquid fuel as fuel and convert it to hydrogen in a suitable converter installed on the car

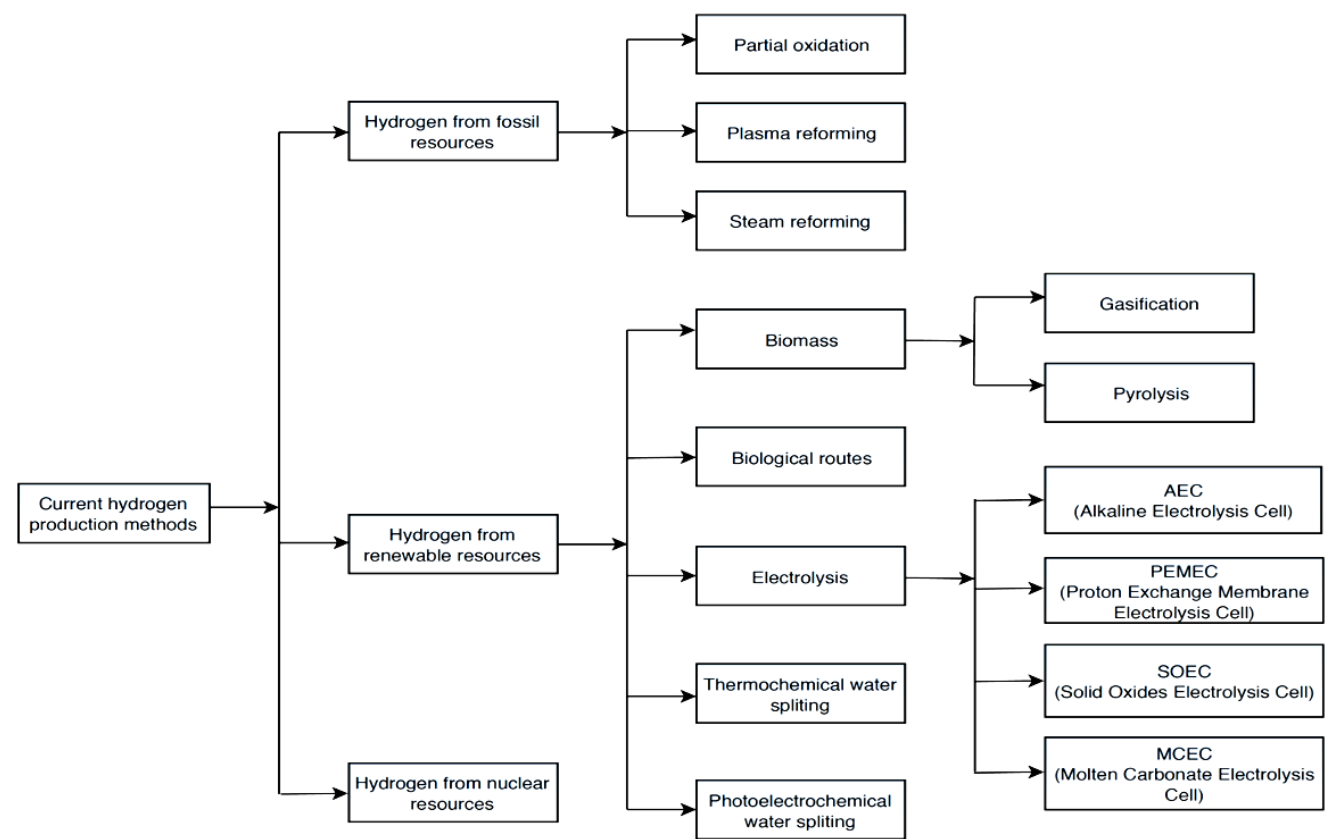

Figure 1. Methods of hydrogen production [12]

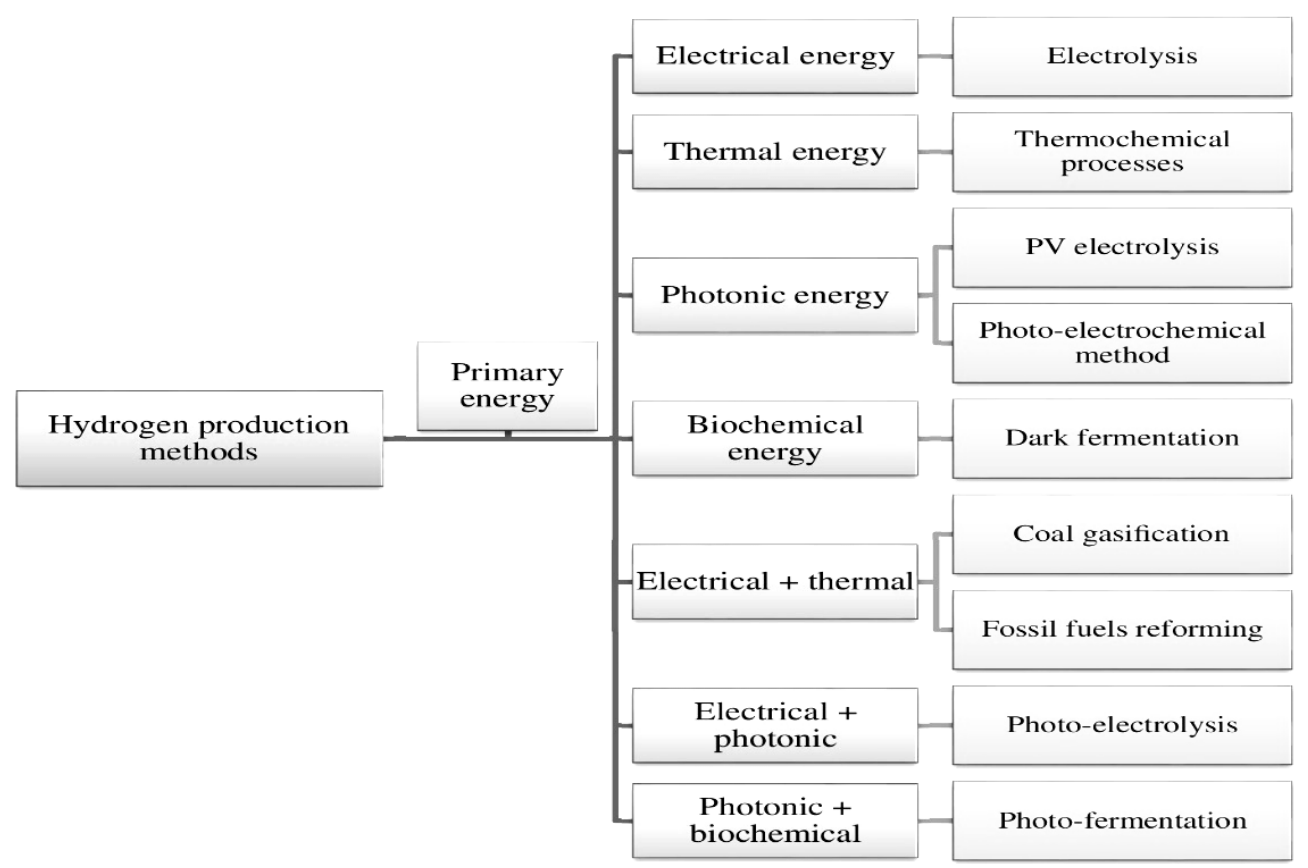

Figure 2. Energy type used in each method of hydrogen production [13]

The prospect of hydrogen as a future fuel is important in two stages of time: 


\title{
I. Hydrogen production from fossil sources
}

- Partial oxidation of heavy oil

- Natural gas converter with gas conversion process by steam (Steam Reformer)

- Partial Oxidation Reformer

\author{
II. Hydrogen production from non-fossil sources (renewables) \\ - Photoelectrochemical \\ - Biological materials \\ - $\quad$ Biochemical \\ - Thermochemical \\ - Water thermolysis \\ - Radiolysis of water \\ - Biomass material \\ - Water electrolysis
}

Although hydrogen is the second most abundant element in nature, hydrogen is not available as an element like conventional fossil fuels. Hydrogen can be obtained from fuels such as coal, oil, or natural gas [14].

Today, hydrogen can be obtained from water electrolysis, natural gas reform, and partial oxidation of fossil fuels. Fossil fuels currently make up $98 \%$ of all hydrogen produced globally; Shortly, hydrogen fuel will power vehicles, heat, and cook at home[15]. At present, hydrogen produced in the industry is considered a chemical product and not fuel. The commercial sale of hydrogen is less than $3 \%$ of the world's production, which is estimated at 20 million tons per year; This means that $90 \%$ of the hydrogen produced is consumed at the production site; Today, for example, the hydrogen industry in the United States produces nine million tons of hydrogen annually, which provides the fuel needed for 20 to 30 million Suzu hydrogen vehicles for 5 to 8 million households [16-50]. An energy carrier is used. Different production methods from different energy sources have unique needs and produce or distribute unique by-products [17].

Further research and development, and prototyping are needed to optimize and diversify commercial hydrogen production methods [18]. Advanced methods for separating pollutants are needed to reduce the price of hydrogen produced and increase efficiency. More suitable methods are needed for both stationary and dispersed hydrogen production for hydrogen production, and efforts should be made on existing commercial processes such as methane reforming, electrolyzers, etc. in the development of advanced techniques such as pyrolysis of biomass materials and separation of water by thermochemical method, electrolysis Focus on electrochemical and biological methods. Hydrogen will be produced in large refineries, industrial areas, energy parks, refueling stations in different communities and easily distributed in rural areas and customers' homes [19].

The hydrogen required (for example, for a fuel cell) can be obtained from a variety of sources, such as primary energy sources (crude oil), secondary energy sources), those produced using primary energy sources, such as hydrogen (renewable sources (those without intervention). Humans are produced intermittently (such as wind, sun, and water) due to the lack of environmental pollution, the production of carbon dioxide, the lack of impact on global warming and high energy density, and the possibility of using and transferring it in various energy uses. Scientists refer to hydrogen as the fuel of the future [2022].

The low density of hydrogen in the gaseous state makes it difficult to use hydrogen as an energy carrier. This means that it has a low energy content per unit volume (about $120.7 \mathrm{~kJ} / \mathrm{kg}$ ) compared to liquid fuels such as gasoline or methanol. And for this reason, it is used as rocket fuel. Liquid hydrogen has the highest energy density compared to all fuels. But it must be stored at very low temperatures $\left(253^{\circ} \mathrm{C}\right)$ and high pressures, making it difficult to store and transport [21]. 
Hydrogen does not exist purely in nature but must be obtained from water or fuels such as coal, natural gas, oil, methanol, and ethanol, which have hydrogen in their molecular structure. Therefore, the fuel cell's hydrogen fuel is provided by the electrolysis of water or conventional fuels' conversion. In the latter case, the presence of fuel converters is mandatory; Therefore, it can be said that the function of the fuel converter is to convert a fossil fuel-rich in hydrogen to hydrogen and other by-products such as $\mathrm{CO}_{2[22]}$. Converters are either used as a separate unit (centralized and decentralized) and reside in power plants (converters installed at the refueling site) or as a converter installed next to the fuel cell in vehicles. The use of converters installed in ships equipped with fuel cells and vehicles, especially in vehicles, complicates the system; But it can use existing fuels in existing infrastructure and distribution networks [23].

The fuel exchanger's function is to provide the fuel cell's hydrogen using the available fuels and easy transport. Fuel converters must be able to do this with the least pollution and the highest efficiency. The function of fuel converters, in simple terms, is to convert a hydrogen-rich fuel into hydrogen and other by-products $\left(\mathrm{CO}_{2}\right)$ [24].

One of the major problems of converters installed on cars is the converter's weight and volume. To improve the efficiency level, it is necessary to reduce the weight and volume of converters per unit of electrical energy generated by the system as much as possible; Similarly, the cost of manufacturing converters must be kept low so that the high cost of this technology does not prevent mass production of the car, and the second problem in this regard is the purity of hydrogen produced from the converters. There are sulfurspecific fuel properties in the converters, whose input fuel is natural gas or petroleum derivatives [25]. These sulfur-containing organic compounds must be removed from the fuel; Because sulfur acts as a catalyst for converter catalysts. In natural gas, sulfur compounds are odorous compounds that are added to the gas for safety. The design of the desulfurization system must be done carefully to ensure the absence of sulfur derivatives in the gas passing through the converter catalysts. For this purpose, a reactor is used in which hydrogenation reactions in the presence of nickel molybdenum or cobalt molybdenum oxide catalysts are used. And during a series of chemical reactions, the sulfurous organic compounds are converted to hydrogen sulfide gas [26]. There are several ways to produce hydrogen. Hydrogen can be obtained by converting fossil fuels (gasoline, oil, natural gas, etc.) into fuel converters or by using renewable energy (wind, solar, etc.) and electrolyzer (water decomposition) hydrogen extraction [27].

\subsection{Steam reforming of hydrocarbons}

Conversion of natural gas by steam is one of the common methods of hydrogen production. Methane (the main element of natural gas) participates in the equilibrium reaction with steam, and the reaction product is mainly hydrogen and carbon monoxide [28]:

$$
\mathrm{CH}_{4}+\mathrm{H}_{2} \mathrm{O} \rightarrow \mathrm{CO}+3 \mathrm{H}_{2}
$$

The main role of steam in steam conversion reactions is to direct the equilibrium towards the production of $\mathrm{CO}$ and $\mathrm{H}_{2}$, and due to the equilibrium of the reaction, as the pressure decreases, the reaction proceeds to produce more hydrogen molecules. In addition to methane, other hydrocarbons can also participate in the water vapor conversion reaction to produce hydrogen. Hence, the general form of the water vapor conversion reaction can be shown as follows [29]:

$$
C_{m} H_{2 m+2}+n H_{2} \mathrm{O} \leftrightarrow m C O_{2}+\left(n+\frac{2 m+2}{2}\right) H_{2}
$$

This reaction is highly endothermic, and to produce more hydrogen and carbon monoxide, the reaction must be performed at high temperature and low pressure. The pressure 
is usually constant; therefore, raising the reaction's temperature causes it to produce hydrogen [30]. To provide such a high temperature (about 2 to $3^{\circ} \mathrm{C}$ ), place the reactor in which the reaction occurs in the radiant part. In this process, the ratio of vapor to carbon in the feed is 3.5; Therefore, under these conditions, $4 \%$ of methane is converted to hydrogen, and if a higher conversion of methane is required, it can be converted from a second converter (partial oxidation converter). A certain amount of oxygen or air reacts with the exhaust gas from the first converter in the catalyst's vicinity in the second converter. This reaction causes the gas to oxidize, resulting in a higher share of methane converted to hydrogen. Using the second converter, more than $1.6 \%$ of methane is converted to hydrogen. The advantage of having a steam exchanger and partial oxidation over a steam exchanger is that there is no need to operate the first steam exchanger in harsh high-temperature conditions; In other words, in the two-converter system, the first steam converter operates at a lower temperature, while in the two-converter system, the efficiency and amount of conversion increase and the cost of devices and equipment decreases. If natural gas is used as fuel in the fuel cell device, a natural gas converter is used [30-32].

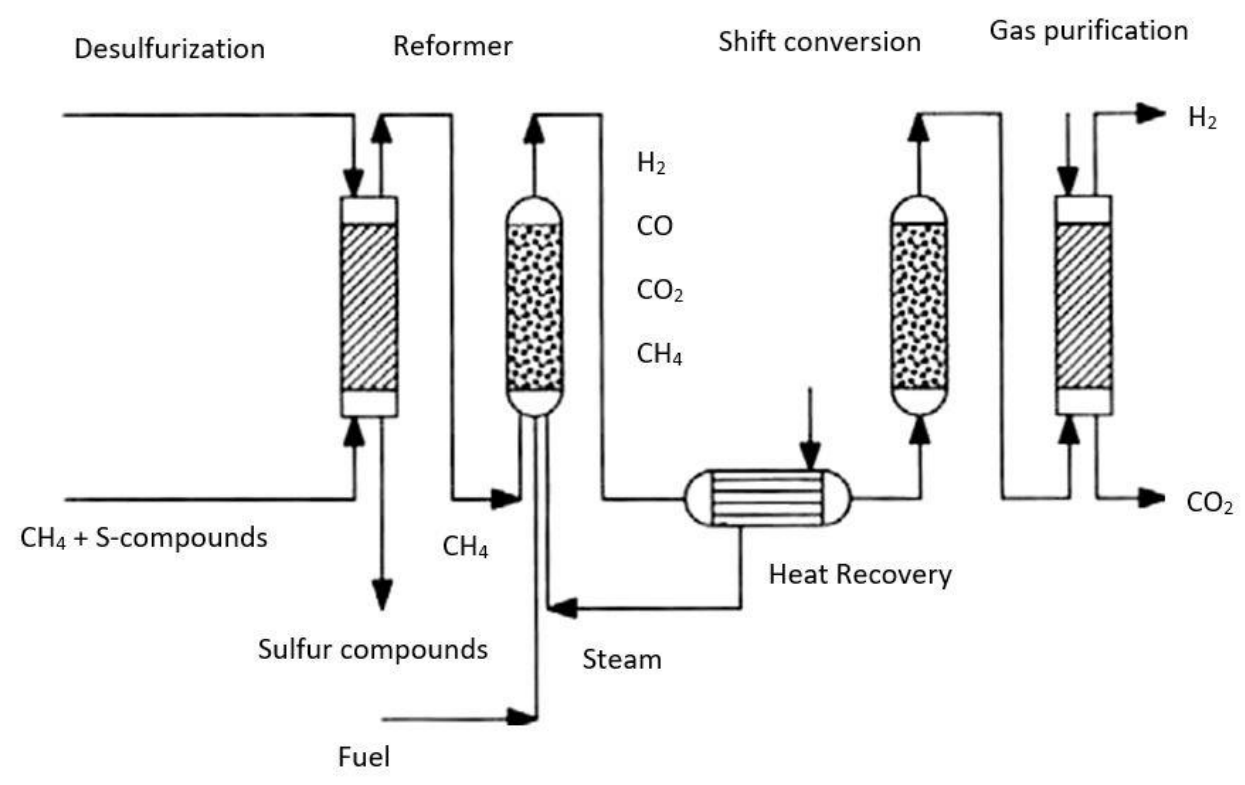

Figure 3. Methane Reforming process

\subsection{Converted natural gas converter using partial oxidation}

In cases where natural gas is not economical or heavy oil is available cheaply, partial oxidation produces hydrogen. Residues from chemical processes are preferably used to produce hydrogen and carbon monoxide. Minor oxidation reactions include the following [34]:

$$
\begin{gathered}
\mathrm{C}_{n} \mathrm{H}_{m}+\frac{n}{2} \mathrm{O}_{2} \leftrightarrow n \mathrm{CO}+\mathrm{H}_{2}+\text { Heat } \\
\mathrm{C}_{n} \mathrm{H}_{m}+n \mathrm{H}_{2} \mathrm{O}+\text { Heat } \leftrightarrow n \mathrm{CO}+\left(n+\frac{m}{2}\right) \mathrm{H}_{2} \\
\mathrm{CO}+\mathrm{H}_{2} \mathrm{O} \leftrightarrow \mathrm{CO}_{2}+\mathrm{H}_{2}+\text { Heat }
\end{gathered}
$$

Partial oxidation is an exothermic reaction and occurs at high temperatures (between 2 and $4{ }^{\circ} \mathrm{C}$ ) without a catalyst [35]. The advantage of using this method over catalytic processes is that there is no need to purify materials such as sulfur derivatives. Sulfur, 
however, must be accelerated in later stages. High temperatures in partial oxidation make it possible to use heavier oil slices that could not be consumed in catalytic processes and converted to hydrogen in this process [36]. The high operating temperature has made the application of this process on a small scale several problems. The use of catalysts causes the process temperature to decrease, called the partial catalytic oxidation process.

The catalysts used in CPO are based on platinum and nickel. In the partial oxidation process, less hydrogen is produced per methane molecule than in the water vapor conversion process, which means that the partial oxidation efficiency (catalytic or non-catalytic) is lower than that of the water vapor conversion process. Also, due to the exothermic reaction of the conversion in this process, the heat generated in the cell can not be used, and therefore, the cell's efficiency is slightly low [37].

A partial oxidation converter is used to prepare fuel cells. In this converter, the reaction temperature and the reactor temperatures are controlled by changing the air ratio to fuel; Hence, no other heat exchanger is required [38].

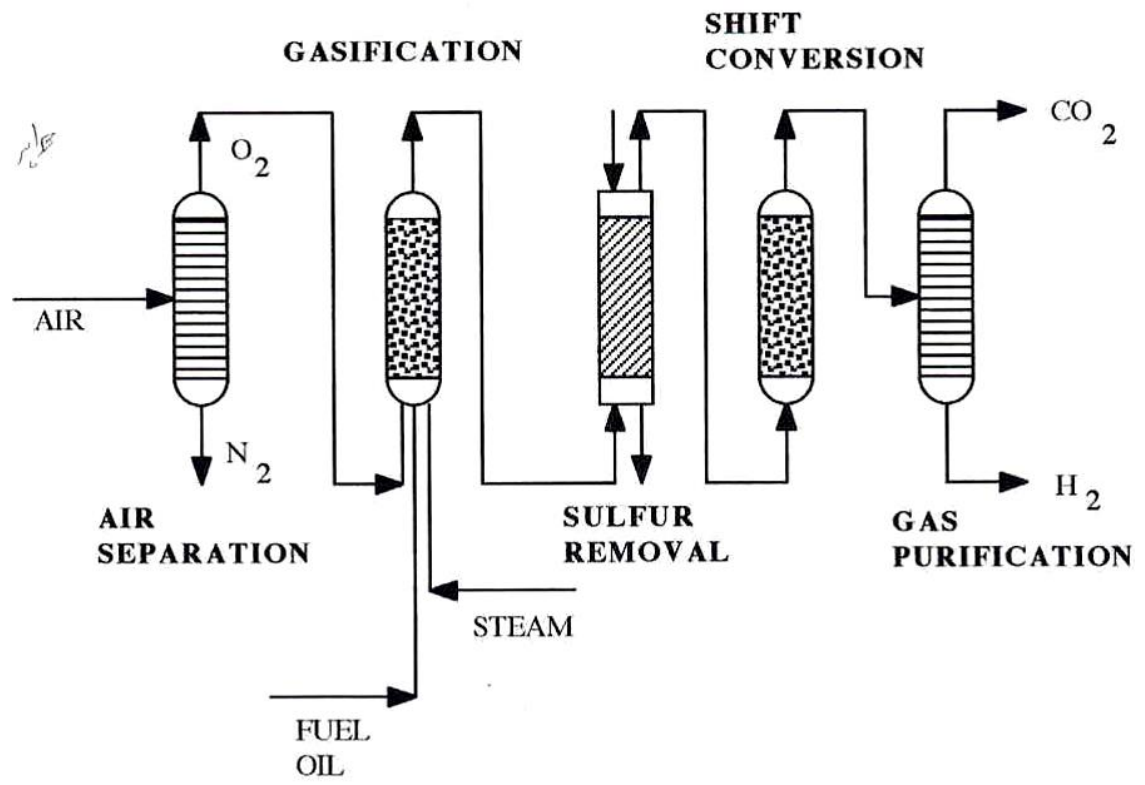

Figure 4. Process of the fuel-oil partial oxidation method

\subsection{Auto thermal Method}

Auto thermal conversion is another method used in fuel conversion. In this process, a water vapor and oxidizer (oxygen or air) mixture is introduced into the reactor burner and then passes over the catalyst's surface at high temperatures. This process is a mixture of exothermic reactions of partial oxidation and heat exchanger converted to water vapor, and the partial oxidation reaction provides the energy required for the reaction with water vapor conversion. Therefore, changing the air ratio to fuel controls the reaction temperature and reactor temperature. For all hydrocarbon fuels $\left(\mathrm{C}_{n} \mathrm{H}_{\mathrm{m}} \mathrm{O}_{\mathrm{p}}\right)$, the partial oxidation reaction is as follows [39]:

$$
C_{n} H_{m} O_{p}+x\left(O_{2}+3.76 N_{2}\right)+(2 n-2 x-P) H_{2} O \rightarrow n C O_{2}+\left(2 n-2 x-P+\frac{m}{2}\right) H_{2}+3.76 x N_{2}
$$

In the above reaction, $x$ is the ratio of air to fuel. Temperature and reaction are just a function of $x$. When $x$ is zero above reaction will be a water vapor conversion reaction that 
is very superheated, and as the value of $x$ increases, the intensity of the exotherm decreases until, in a certain ratio, the reaction is neither exothermic nor exothermic; That is why this type of converter is called Auto thermal [40]. The advantage of this auto thermal process is that it requires less water vapor than conventional systems, and all the heat required for the reaction is provided by the combustion of part of the fuel; Therefore, its heat management is simple and does not require complex systems [41].

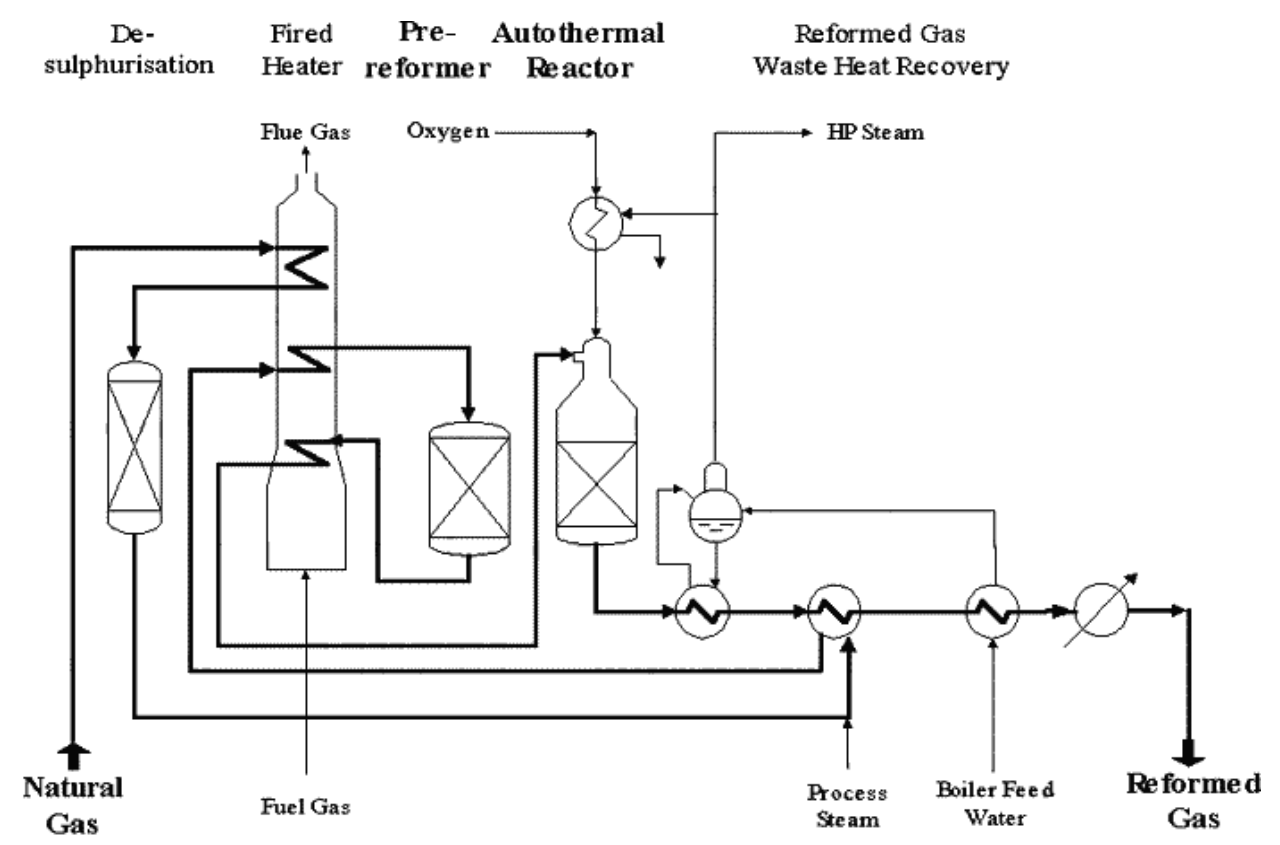

Figure 5. Methane Auto-thermal process

\subsection{Pyrolysis Method}

Pyrolysis is when organic matter is degraded by heat in the absence of oxygen to form water vapor, new gases, volatiles, tar, and coal, hence destructive distillation. The pyrolysis reaction for the biomass begins at 300 to $375^{\circ} \mathrm{C}$. Coal, organic liquids, gas, and water are obtained in different proportions from this process, and their ratio and amount depend on the operating temperature, heating rate, retention time, type of raw materials and their moisture content. More gas is produced at higher temperatures and longer residence times, while more coal and liquids are produced at lower temperatures and shorter residence times [42-44].

The solids formed in this process are coal (activated carbon) and ash. The resulting liquids contain organic compounds with a lighter molecular weight than the compounds of the raw material. These compounds include acids, alcohols, aldehydes, columns, esters, phenolic compounds. In the resulting gas, the following compounds are more common: carbon monoxide, hydrogen, carbon dioxide, methane, ethane, ethylene, water vapor, and other hydrocarbons in small amounts [41].

The coal obtained from the combustion process is 30 times more active than ordinary coal, so one of the advantages of this process is the production of activated charcoal (carbon), which is widely used in refining and removing impurities from various materials (especially in water treatment from Chemical compounds). Coal production efficiency increases at lower temperatures $\left(300-500{ }^{\circ} \mathrm{C}\right)$ and shorter residence times (about seconds). This process is also called carbonization $[45,46]$.

In addition to the above methods, there is another way to produce hydrogen from hydrocarbons, which is to heat the hydrocarbons in the absence of air, during which the hydrocarbons are broken down and decomposed into hydrogen and solid carbon. The 
advantage of the thermal refraction process is that hydrogen is produced with high purity. The problem is the presence of solid carbon that must be removed from the reactor. By adding air to the hot reactor, carbon is released from the system as carbon dioxide. Recently, the propane thermal refraction process to supply hydrogen for use in polymer fuel cell systems has been proposed [47].

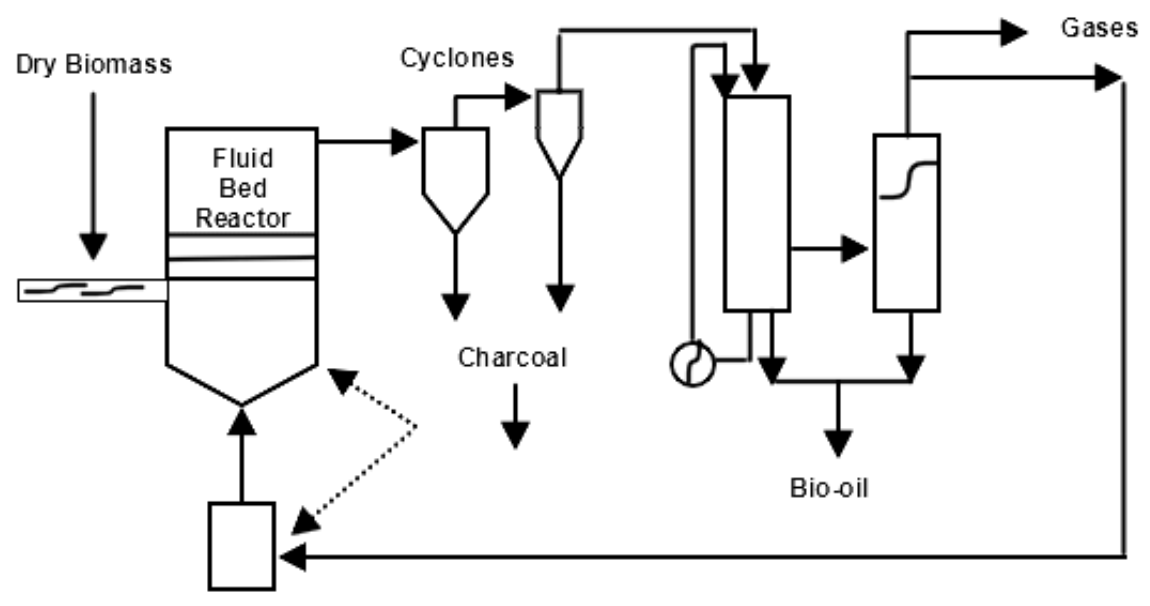

Figure 6. Biomass pyrolysis process

\subsection{Coal gasification}

This method is based on the partial oxidation of input materials with a carbon base and their conversion to artificial gas. This technology also has a long history in the industry and was common in developed countries to extract gas from coal or oil before providing easy oil and natural gas access. This technology in solid waste treatment began in 1980, but many factories could not continue to operate. With the increasing development of technology and the need to prevent waste entry into landfills, this technology has expanded in recent years, especially in Europe and Japan [48, 49].

The result of initial experiences in this field indicates the need to perform a minimum of preprocessing for proper gasification performance. This preprocessing involves separating bulky and inorganic wastes and processes, such as shredding and drying [50].

In the gasification method, $10 \%$ to $30 \%$ of the waste's calorific value is first oxidized to produce primary energy. This primary energy produces synthetic gas consisting of methane, hydrogen, and carbon dioxide. Air, oxygen, or water vapor is injected into the gas reactor [51].

Gas reactors are usually available horizontally and vertically and have three types of design:

- $\quad$ Fixed bed

- Fluid bed

- $\quad$ Stretched bed

The difference between these reactors is how oxygen enters, how raw materials enter, and the direction of movement of materials in the reactor. If the gasification occurs at a high temperature, the inorganic material melts in the reactor and forms a non-hazardous glass slag after cooling [52].

The gasification of coal is a process in which coal is converted to gas. Coal is usually gassed using pure oxygen ( 95\%) at high temperatures and pressures to produce hydrogen or hydrogen-rich gas.

$$
2 \mathrm{C}+\mathrm{O}_{2} \rightarrow 2 \mathrm{CO}+\mathrm{Heat}
$$




$$
\mathrm{C}+\mathrm{H}_{2} \mathrm{O}+\mathrm{Heat} \rightarrow \mathrm{CO}+\mathrm{H}_{2}
$$

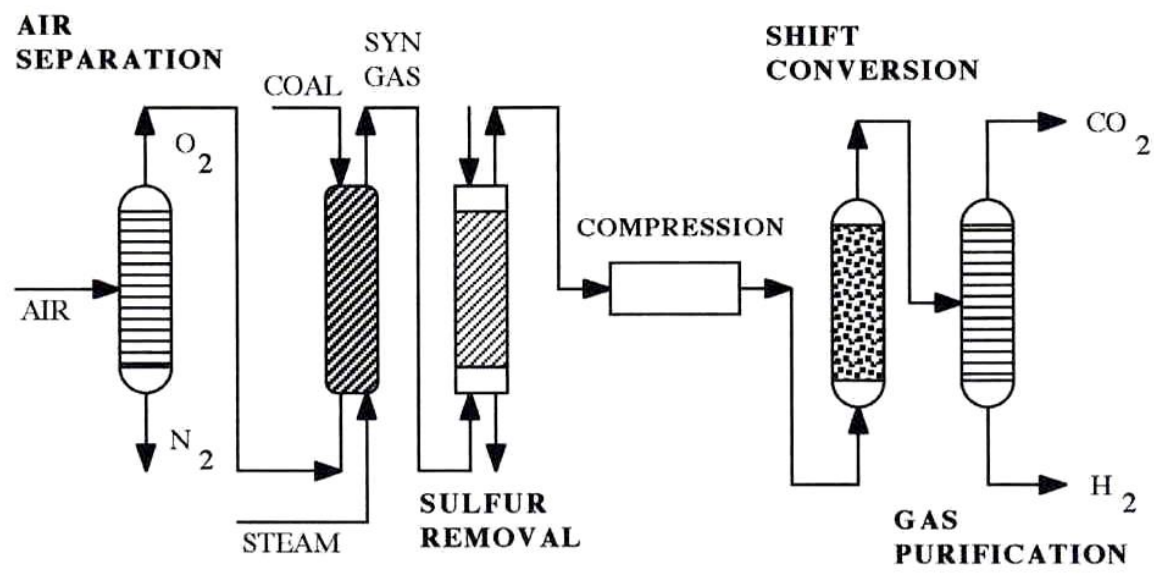

GASIFICATION

Figure 7. Coal gasification process

\subsection{Steam Iron-process}

The iron steam process is one of the oldest ways of producing hydrogen. This process is based on coal. Coal gas is used to reduce iron oxide and convert it into iron. Hydrogen is produced by the interaction of steam with iron oxide. In the first stage, coal is gassed under the influence of steam and air to produce hydrogen and carbon monoxide, reducing gases [53].

$$
\begin{aligned}
& 2 \mathrm{C}+\mathrm{O}_{2} \rightarrow 2 \mathrm{CO}+\text { Heat } \\
& \mathrm{C}+\mathrm{H}_{2} \mathrm{O}+\mathrm{Heat} \rightarrow \mathrm{CO}+\mathrm{H}_{2}
\end{aligned}
$$

In the second stage, these gases react with iron oxides to form reduced forms of iron oxides.

$$
\begin{aligned}
& \mathrm{Fe}_{2} \mathrm{O}_{3}+\mathrm{H}_{2} \rightarrow 3 \mathrm{FeO}+\mathrm{H}_{2} \mathrm{O} \\
& \mathrm{Fe}_{3} \mathrm{O}_{4}+\mathrm{CO} \rightarrow 3 \mathrm{FeO}+\mathrm{CO}_{2} \\
& \mathrm{FeO}+\mathrm{H}_{2} \rightarrow \mathrm{Fe}+\mathrm{H}_{2} \mathrm{O} \\
& \mathrm{FeO}+\mathrm{CO} \rightarrow \mathrm{Fe}+\mathrm{CO}_{2}
\end{aligned}
$$

The most important drawback of the iron vapor process is that only $60 \%$ of the potential gas volume is used for reduction. In the third stage of the reaction, the reduced components are re-oxidized in water, and the generated iron re-enters the steam-iron reactor. The result is the presence of steam, some $\mathrm{Fe}_{3} \mathrm{O}_{4}$, and hydrogen-rich gas [54]. 


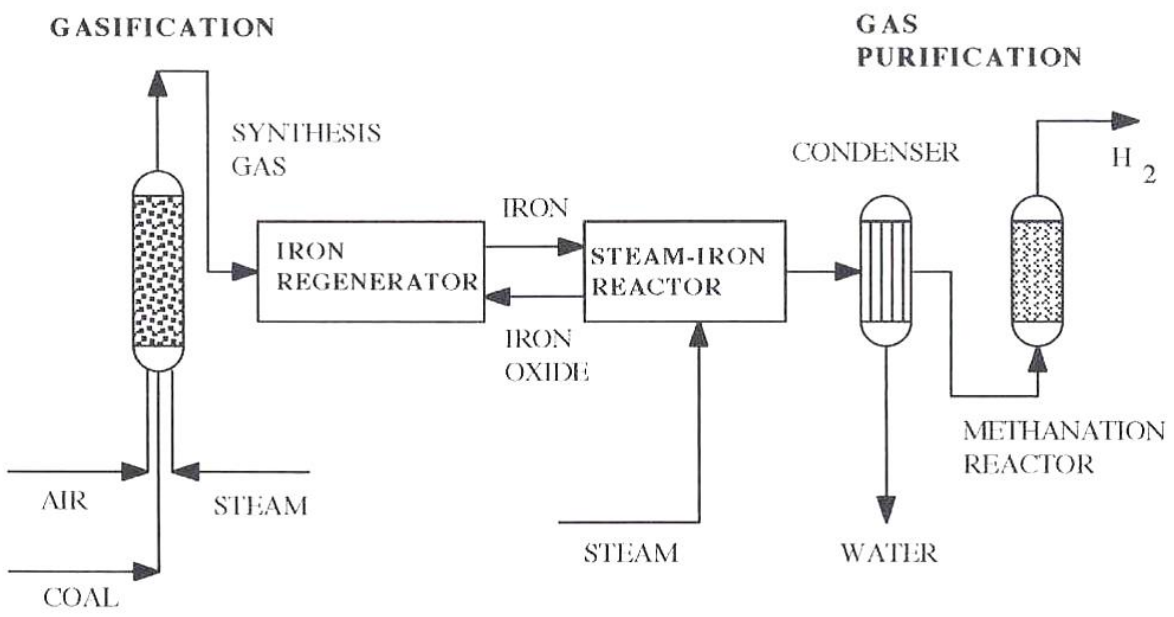

Figure 8. Steam iron process schematics

\subsection{Water electrolysis}

The principles of water electrolysis were first introduced by Michael Faraday in 1820 and is a process in which hydrogen and oxygen are produced from water. The word lysis means to dissolve or separate; also, electrolysis means breaking and separating (here water) using electricity. Water electrolysis is a very simple process in which electricity is passed through a solution containing water and electrodes. According to the figure below, the electrolysis device works so that the battery's negative pole is connected to the cathode (negative electrode) and the battery's positive pole is connected to the anode (positive electrode). There is a tendency to absorb electrons in the anode electrode. Water has a low electrical conductivity to conduct electricity, so electrolytes are added to increase the electrical conductivity in the electrolysis process [55].

The water molecules around the cathode electrode are separated into $\mathrm{OH}^{-}$and $\mathrm{H}^{+}$ ions, and the number of water molecules around the cathode decreases, and the $\mathrm{OH}$ concentration increases. The water molecule is expected to separate into an $\mathrm{H}^{+}$ion and an $\mathrm{OH}^{-}$ ion, but this does not happen because the oxygen atom has more electronegativity than the hydrogen atom [56].

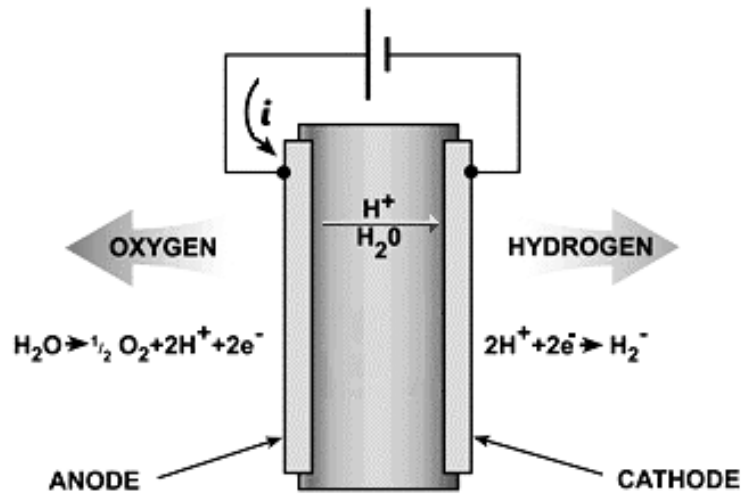

Figure 9. Water electrolysis process 


$$
\mathrm{H}_{2} \mathrm{O} \rightarrow \mathrm{H}^{+}+\mathrm{OH}^{-}
$$

So this causes the outer surface of the cathode to be completely covered by hydroxide ions, but the $\mathrm{H}^{+}$ion lacks protons and tries hard to take an electron and turn it into a hydrogen atom [57]:

$$
H^{+}+e^{-} \rightarrow H
$$

This hydrogen atom collides with another hydrogen atom to form a molecule of hydrogen gas, and this molecule of hydrogen gas comes out of the water in the form of bubbles [58]:

$$
\mathrm{H}+\mathrm{H} \rightarrow \mathrm{H}_{2}
$$

At the same time, hydroxide ions $\left(\mathrm{OH}^{-}\right)$migrate to the anode and reach the anode's surface. The anode takes back the extra electrons taken by the hydroxide ions from the hydrogen, and the hydroxide ion again forms one molecule of oxygen gas and two molecules of water with the other three molecules of hydroxide. The oxygen molecule is stable and comes to the surface in the form of bubbles [59].

$$
\begin{aligned}
& 4 \mathrm{OH}^{-} \rightarrow \mathrm{O}_{2}+2 \mathrm{H}_{2} \mathrm{O}+4 e^{-} \\
& \mathrm{H}_{2} \mathrm{O} \rightarrow \frac{1}{2} \mathrm{O}_{2}+2 \mathrm{H}^{+}+2 e^{-} \\
& 2 \mathrm{H}^{+}+2 e^{-} \rightarrow \mathrm{H}_{2}
\end{aligned}
$$

Also, equations 19 and 20 present the anodic and cathodic reactions, respectively.

\subsection{Electrochemical reduction method}

Formic acid can be produced with four different chemical methods, including the electrochemical reduction of $\mathrm{CO}_{2}, \mathrm{CO}_{2}$, and $\mathrm{H}_{2}$, implementing homogeneous catalysis, hydrolysis of formamides, and synthesis photocatalysis route [48]. All of these methods contain specific advantages and disadvantages. In this paper, a thermos-economic assessment was implemented on the $\mathrm{CO}_{2}$ electrochemical reduction reaction, considering various available scenarios of this method. The electrochemical reduction model consists of an electrochemical reactor, water electrolyzer, and carbon capture unit [47]. The power consumption of these plants is provided with a photovoltaic field. The $\mathrm{CO}_{2}$ as a reactant is entered into the electrochemical reduction in the cathodic side, and water is entered into the electrochemical reduction anodic side. The pressure of these raw materials and inputs are controlled using the peristaltic pumps. In the reactor, the electrolyte is placed in the cell, and the electrochemical reduction reaction occurs. The process outcomes are separated in a distillation tower in which formic acid is the main product. The by-products, such as hydrogen and oxygen, are extracted directly from the reactor using a compression unit [49].

Figure 100a illustrates a schema of the formic acid synthesis's electrochemical process from water and carbon captured by the combined cycle plant. This process uses a voltage source and consumes power to increase the electrical potential between the cathode and the anode. This process's electrolyze cell is a unique CDU cell comprising many layers of different materials (see Figure 100b). They catalyze the rate of reaction and increase the formic acid synthesis rate. This cell is called a chemical electrolyze cell in which the anolyte and catholyte are simulated using the electrical potential to react in a controlled oxidation, and reduction process in which the reduction product is the formic acid-some other products like $\mathrm{H}_{2}, \mathrm{O}_{2}$, and metallic ions are due to this reaction [51]. 

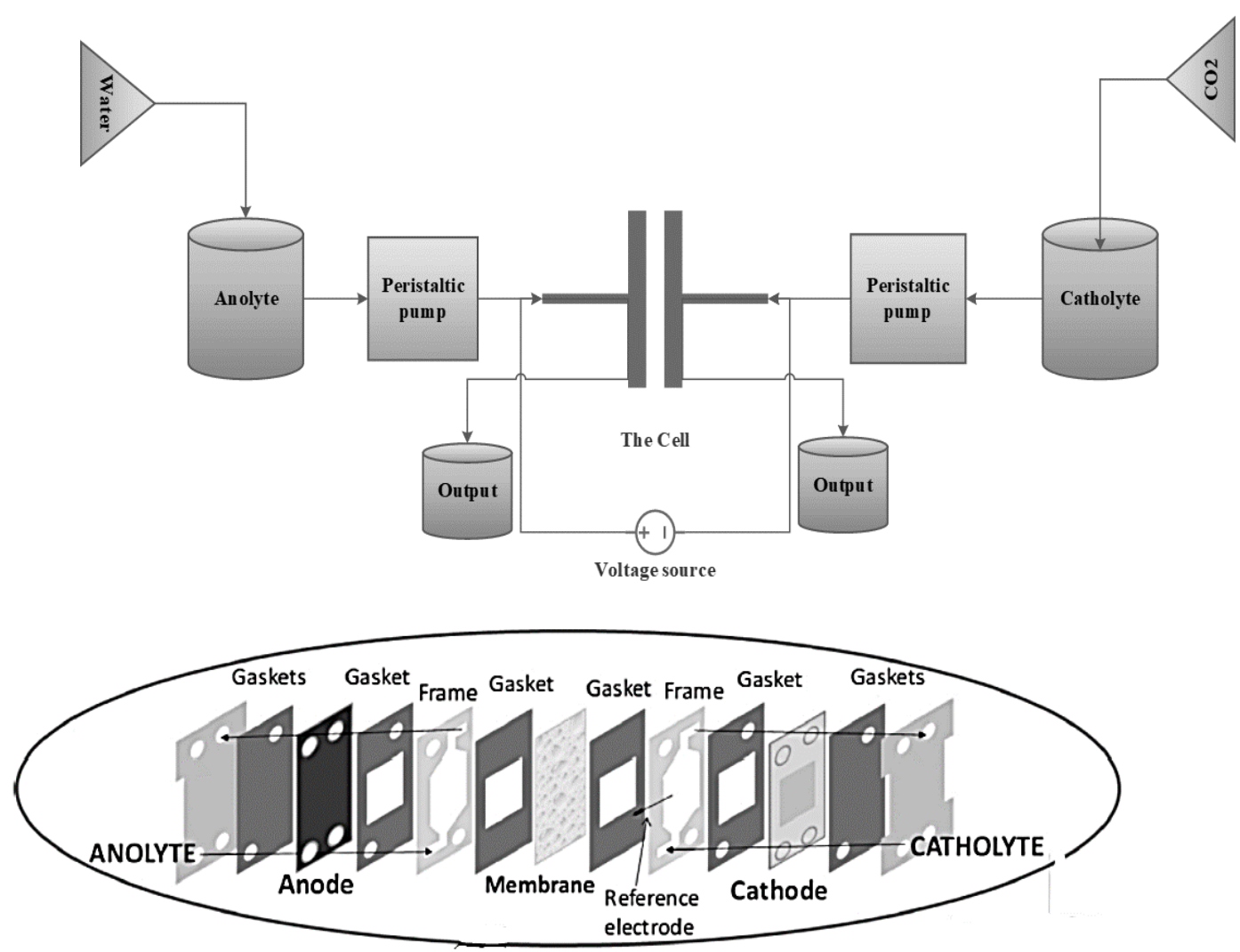

Figure 10. (a) The electrochemical reduction reactor of CDU plant, and (b) chemical electrolyzer cell of CDU plant

\subsection{Photochemical method}

Hydrogen has been labeled the fuel of the future because it contains no carbon, has the highest specific combustion enthalpy of any chemical fuel, produces water only after complete oxidation, and is not limited by Carnot considerations in the amount of work obtained when used in a fuel cell [58]. To be used on the scale required for sustainable growth on a global scale, hydrogen must be produced by the light-driven splitting of water into its elements instead of reforming methane, as is currently being done. The photochemical generation of $\mathrm{H}_{2}$, the reductive side of the water-splitting reaction, is central to this report, particularly concerning the work done in the senior author's laboratory over the past five years. Despite pioneering work done more than 30 years ago and the extensive research that has since been conducted on all aspects of the process, no viable system has been developed for the efficient and robust photogeneration of $\mathrm{H}_{2}$ from water using only soil-rich elements[59]. For the photo-generation of $\mathrm{H}_{2}$ from water, a system must contain a light absorber, a catalyst, and an electron source. This report describes the discovery and study of new $\mathrm{Co}$ and $\mathrm{Ni}$ catalysts that suggest $\mathrm{H}_{2}$ forms via a heterocoupling mechanism of a metal hydride and a ligand-bound proton. Several complexes with redox-active dithionic ligands have recently been recognized to promote the response [60]. 


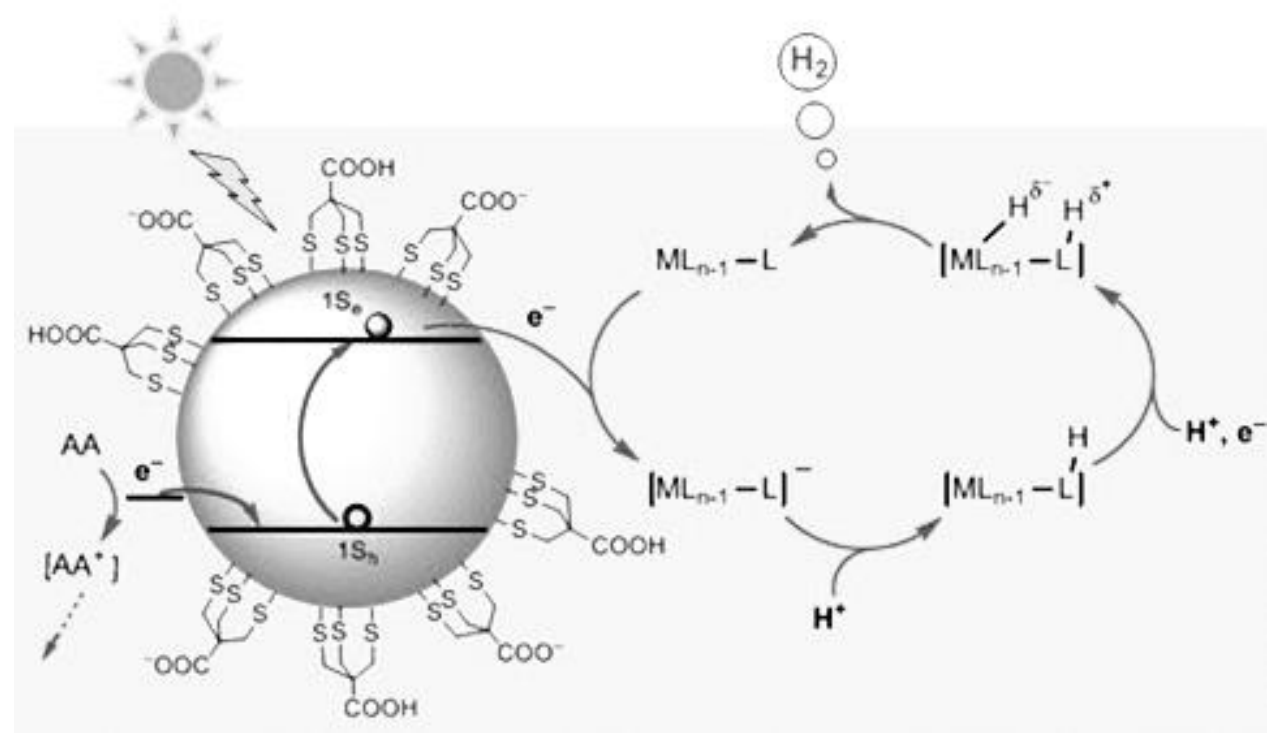

Figure 11. The photochemical hydrogen generation process

\section{Hydrogen Economy}

\subsection{Challenges of a hydrogen economy}

\subsubsection{The generation and use of hydrogen are ineffective}

Hydrogen is an energy carrier that, like electricity, must be generated from other energy sources such as fossil fuels, nuclear energy, or renewable energy. The most common techniques for producing hydrogen (thermochemical or electrolytic) have an efficiency of $60 \%-70 \%$, based on the lower calorific value of hydrogen $[1,12]$.

This energy (and economic) cost has led to criticism that hydrogen is less efficient than other methods to reduce oil consumption or carbon dioxide $\left(\mathrm{CO}_{2}\right)$ emissions. For example, producing hydrogen from natural gas for use in a car is typically less efficient than using natural gas directly, even though a hydrogen vehicle with a fuel cell is more efficient than a vehicle-natural gas hybrid (Figure 122) [13]. Similarly, if renewable electricity is generated, it can be used directly to reduce power plants' coal consumption (and $\mathrm{CO} 2$ emissions). Another possibility would be to use renewable electricity to generate hydrogen for cars, but this option does not produce the same level of reduction in $\mathrm{CO}_{2}$ emissions (Figure 133). Hydrogen production by water electrolysis is considered especially ineffective since it requires two conversions: producing electricity from fossil fuel and producing hydrogen from electricity[21].

The total efficiency calculations illustrated in Figures 12 and 13 may be useful for process analysis, but they do not consider all possibilities. For example, electrolytic hydrogen generation can be attractive from a power system perspective [22]. In the early stages of the transition to hydrogen, electrolytic hydrogen production can be done on a small scale in homes, hotels, and buildings, where the hydrogen generated can be used to power automobiles. In contrast, the heat generated in the electrolysis process can be used efficiently to heat water and cook, among other activities, in a co-generation process. In this way, fossil fuels can be consumed in large-scale power plants, allowing the capture and geological storage of the $\mathrm{CO}_{2}$ produced. Most of the electricity will likely be generated without producing $\mathrm{CO}_{2}$ from nuclear, solar, or wind energy in the long term. An electrical system of these characteristics needs to have an excess capacity to compensate for renewable resources' natural variability [19]. Excess electricity generation would normally go to waste since there is no practical method of storing electricity on a large scale. However, excess electricity can generate hydrogen, which can be stored and transported for use in cars. In the long term, hydrogen provides synergy between the renewable electricity grid 
and the transportation sector. This synergy is essential to implement renewable electricity networks of reasonable cost[28].

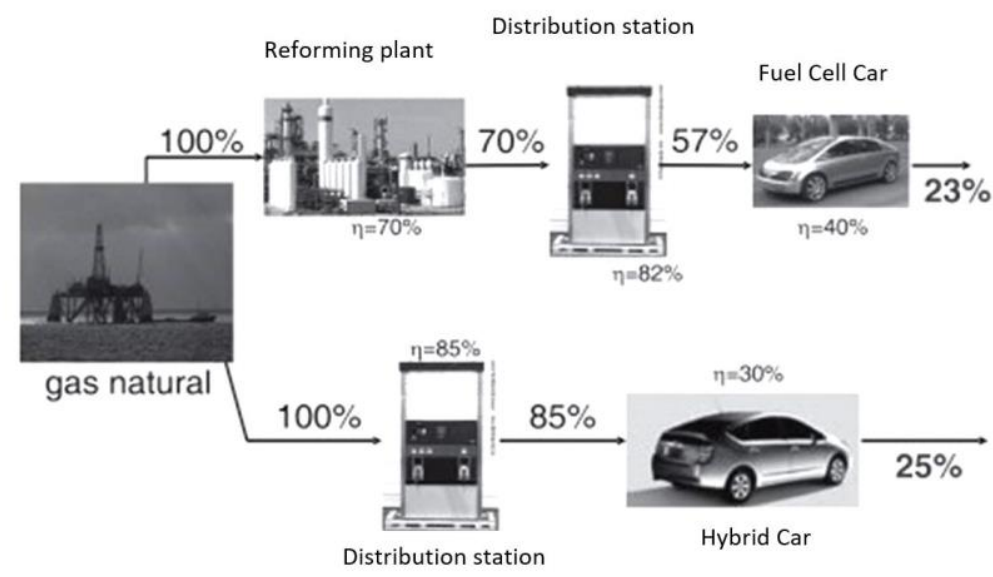

Figure 12. Natural gas utilization efficiency is higher if used directly in vehicles rather than converted to hydrogen. However, this total efficiency analysis does not consider the synergies in energy systems[1,5].

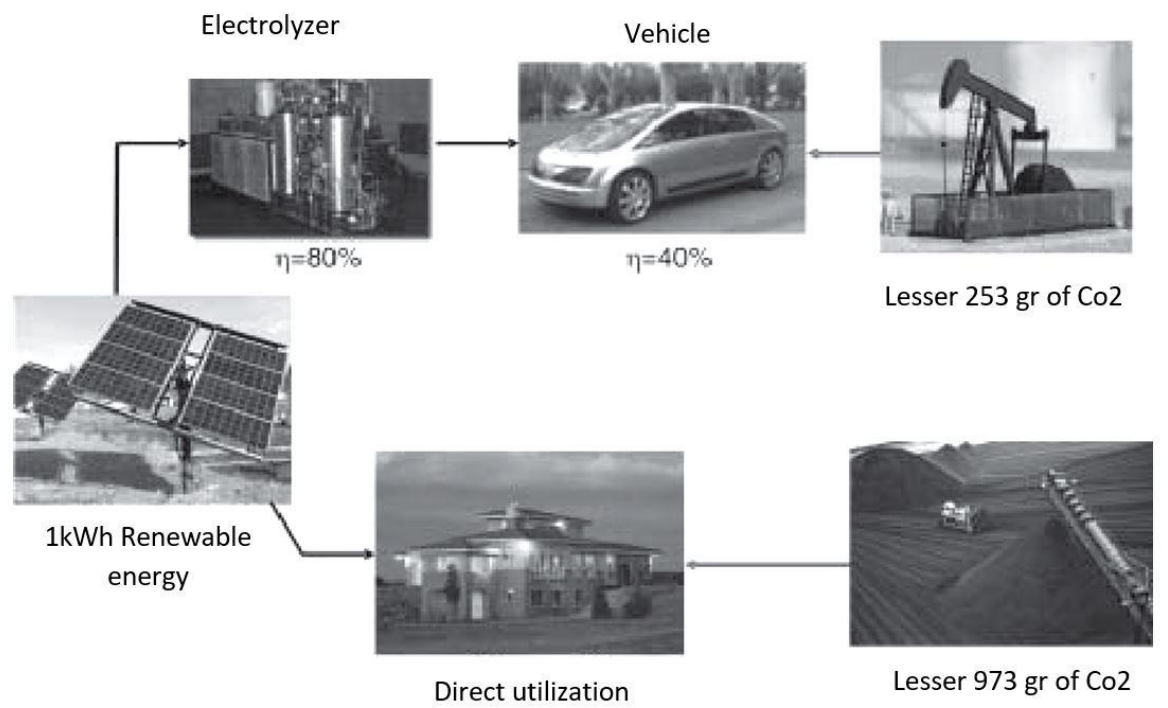

Figure 13. Renewable energy is most effective in reducing $\mathrm{CO}_{2}$ emissions if used directly to reduce coal use in power plants. If hydrogen is generated from renewable energy, a lower reduction in emissions is obtained. However, this total efficiency analysis does not consider the synergies in energy systems [1-10].

Hydrogen can be produced from fossil fuels using thermochemical processes (coal gasification or natural gas reforming) with an efficiency higher than the efficiency of electricity generation or the production efficiency of other synthetic fuels (such as methanol) [61]. If it is shown in the future that geological capture of $\mathrm{CO}_{2}$ is possible on a large scale, then the production of hydrogen from fossil fuels would have the additional advantage that the $\mathrm{CO}_{2}$ produced in the process would not be diluted with atmospheric nitrogen, thereby reducing it forms the energy needed to compress $\mathrm{CO}_{2}$ to conditions suitable for underground storage $[53,62]$. 
Typically, much energy is required (between $10 \%$ and $30 \%$ of the lower calorific value) to compress or liquefy hydrogen for vehicles' storage. However, this energy can be recovered if vehicles are designed that take advantage of the thermomechanical energy available in compressed or liquid hydrogen to generate mechanical power or air conditioning. If hydrogen is used in aircraft, the very low weight is an intrinsic efficiency that becomes even more important as its range and speed increase [61].

Total efficiency calculations (Figures 12 and 13) are limited because they usually do not examine symbiotic relationships such as energy storage, $\mathrm{CO}_{2}$ geological capture and storage efficiency, energy and heat co-generation, or temporary variations in both supply and use of energy[62].

The current electricity generation system is a classic example of the limitations of the calculation of total efficiency. Coal power plants are less efficient and more expensive than combined-cycle natural gas plants, producing electricity at a lower cost [63]. On the other hand, natural gas plants required to meet demand during peak periods are less efficient and produce more expensive electricity than coal or combined cycle plants. However, all of them turn out to be the necessary components within an optimal electricity generation system. In short, efficiency is an important parameter but not necessarily a decisive virtue or criterion: cost and other intangibles (safety, reliability, negative environmental impact) [64].

\subsubsection{Hydrogen is expensive}

The hydrogen economy needs to be reasonably costly to be implemented globally. This, at first glance, appears to be difficult. Like electricity, hydrogen must cost more than the energy source from which it was derived. Thus, hydrogen will cost more than fossil fuels until alternative (non-fossil) energy is cheaper than fossil fuels[65].

As fossil fuels begin to run out, their cost will increase until they become more expensive than alternative energy sources. However, until this time, fossil energy producers can keep the price of fuels low enough to prevent alternative energy from developing, as no one will invest in alternative energy if there is no good prospect of profit. Monetary. On the other hand, fossil fuels are not anticipated to be depleted shortly due to the huge deposits of coal globally. Instead, our environment's ability to accept all the pollutants produced by the extraction, distribution, and use of fossil fuels will be depleted[66].

The most serious consequence of the use of fossil fuels is the destabilization of the global climate. The use of fossil fuels releases $\mathrm{CO}_{2}$, which remains trapped in the atmosphere for centuries, altering the climate, the distribution of rain and storms, as well as the sea level; changes that have the greatest impact on drinking water sources, food production around the world and the increase in the frequency and strength of natural disasters. Hence, although the cost of generating $\mathrm{CO}_{2}$ from fossil fuels is not precisely known, it is known to be large and global. Additionally, $\mathrm{CO}_{2}$-induced climate change may take centuries to correct[67].

When the environmental cost is added to the production of energy through fossil fuels and compared to the production of energy through hydrogen, it can be concluded that the hydrogen economy is the most economical option. However, hydrogen is more expensive than fossil energy. Hydrogen generated from electricity through electrolysis at the point of use or produced from fossil fuels with geological capture and storage of $\mathrm{CO}_{2}$ (Figure 144) has a cost similar to the current cost of gasoline in Europe and Japan (the US $\$ 2.03-3.05$ per kilogram of hydrogen, equivalent to the US $\$ 0.80-1.30$ per liter of gasoline) [68-70].

In addition to this, the high cost of hydrogen is offset by its high utilization efficiency. A high-efficiency hydrogen vehicle (30 km-40 km per liter of gasoline-equivalent) operating with hydrogen at the US $\$ 2.03$ per kilogram would cost US \$ 600-800 a year in fuel, similar to the current cost in countries as Mexico or the United States. States where fuel is relatively cheap. Heavy trucks and airplanes are much more sensitive to the cost of fuel 
than private cars. Therefore, there is an additional incentive to implement high-efficiency technologies (fuel cells) in heavy trucks. In airplanes, hydrogen has the intrinsic advantage of being three times lighter per unit of energy than liquid hydrocarbons. This advantage results in a reduction in the wings' size, the turbines' size, the maintenance required, the weight when taking off, the runway's length, and the noise [1, 25, 37].

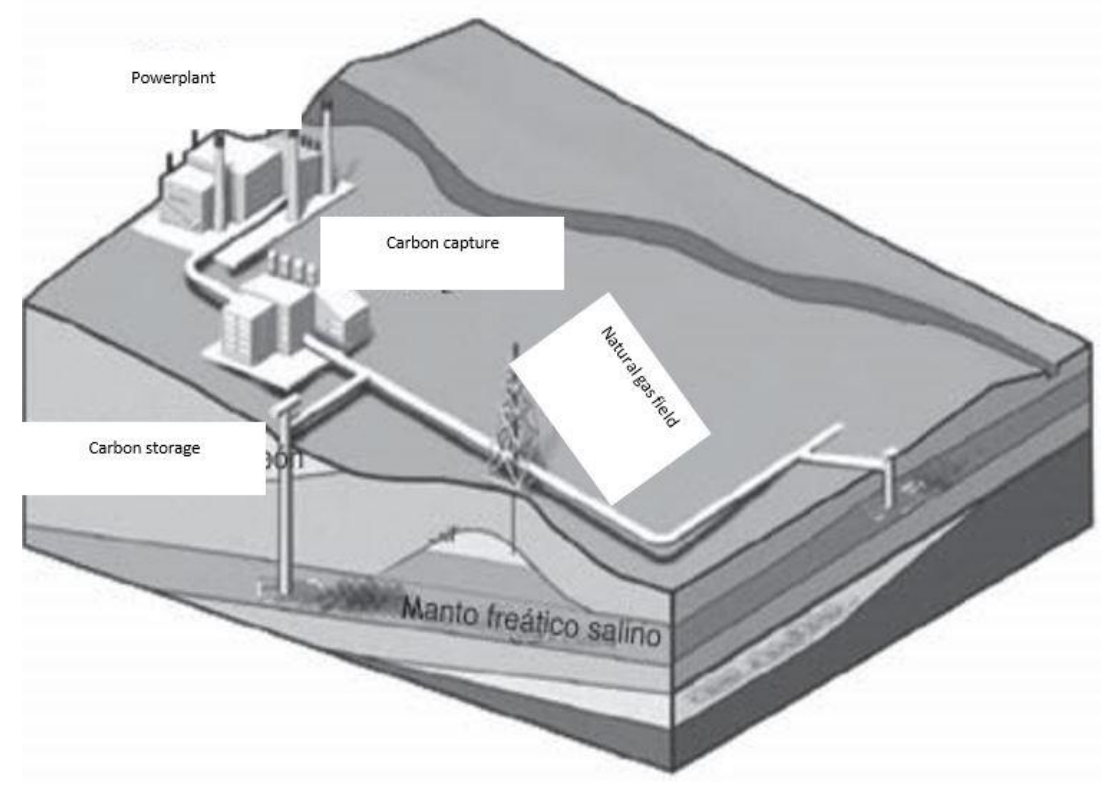

Figure 14. Capture and geological storage of $\mathrm{CO}_{2}$ in oil wells, coal deposits, or saline water tables [13].

In short, hydrogen costs a little more than fossil fuels, but it will be competitive, offering unique benefits: clean combustion, possibly eliminating $\mathrm{CO}_{2}$ emissions, and operating in a closed and inexhaustible cycle based on the cleanest, most abundant substances. And elementals: water, oxygen, and hydrogen (Figure 155); more efficient use, requiring less maintenance and producing less noise; more decentralized and less vulnerable than current systems to terrorism, natural disasters, and supply problems. While there are alternatives to hydrogen that can be used in some particular applications (for example, electric cars for short trips), hydrogen is an inexpensive alternative to fossil fuels that can be used globally in all modes of transport (cars, trucks, planes, and boats) [71]. 


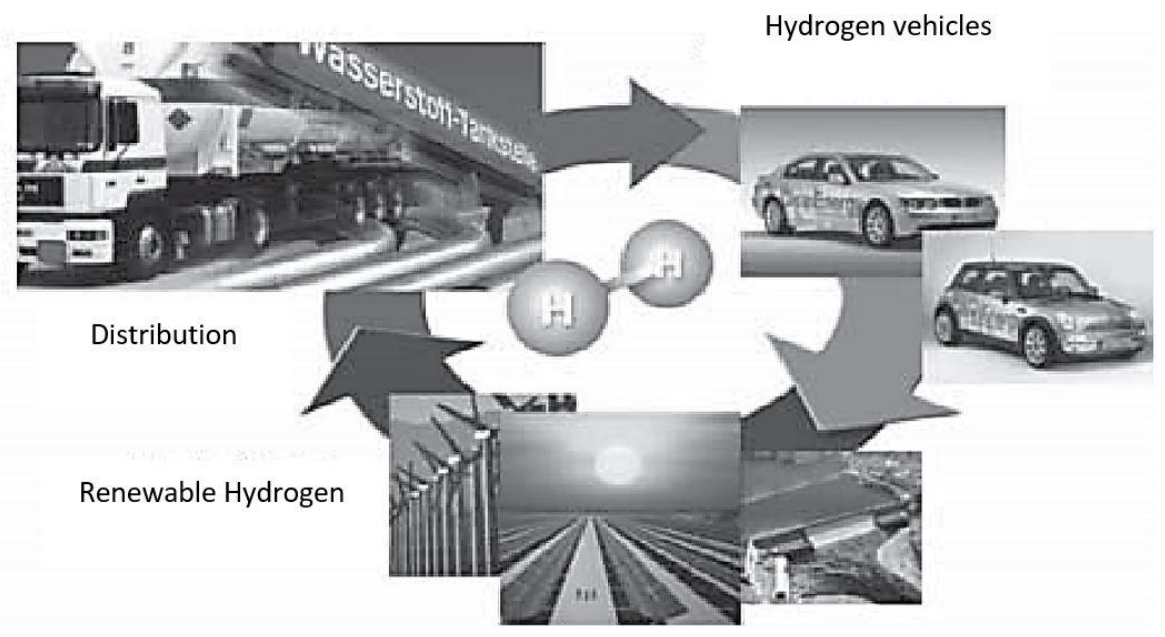

Figure 15. Hydrogen can operate in a closed and inexhaustible cycle based on the cleanest, most abundant, and elemental substances: water, oxygen, and hydrogen [1-6].

\subsubsection{It takes time to introduce hydrogen to the economy}

Some critics have pointed out that oil consumption and $\mathrm{CO}_{2}$ production can be reduced more quickly by introducing policies that improve energy efficiency or promote renewable energy rather than convert the economy to hydrogen [12]. This criticism is correct. Even the most optimistic case analyzed by the National Academy of Engineering of the United States considers that hydrogen vehicles will be introduced on a large scale by 2015 , that all new vehicles will operate with hydrogen by 2040, and that all vehicles will run on hydrogen by $2050[5,34]$.

On the other hand, any change in fuel or energy infrastructure requires a very long transition time [31]. Even oil exploration projects take a long time to complete (a decade). Hybrid vehicles have been sold to the public for five years, and even in 2019, they only make up $2.4 \%$ of all cars sold (from $~ 1 \%$ in 2004). Any large-scale energy transition will inevitably take a long time. The important thing is to plan the transition carefully to obtain the desired result [17].

Efficiency improvements have a rapid impact on the amount of fuel consumed and $\mathrm{CO}_{2}$ produced. However, efficiency by itself is structurally incapable of eliminating $\mathrm{CO}_{2}$ emissions or the use of oil. Efficiency improvements are a relatively quick, easy, and cheap solution (funded by fuel savings), but they also have fundamental limitations [37]. High efficiency reduces (marginal) costs and can result in increased energy demand. After introducing laws requiring increases in automobiles' efficiency in the United States, automobiles' fuel economy increased by $25 \%$ between 1980 and 1990 . However, the distance traveled by a vehicle also increased by $20 \%$ in the same period. As a result, total gasoline consumption remained almost constant [39-41].

This trend is projected to continue in the future. The US Energy Information Administration projects significant increases in electricity and transportation demand by 2025 [22]. The US National Academy of Engineering estimates that the distance traveled by vehicle will increase from $20000 \mathrm{~km}$ to $32000 \mathrm{~km}$ per year between 2025 and 2050, when the transition to hydrogen is expected to occur[27].

These results show that energy efficiency improvement can stabilize $\mathrm{CO}_{2}$ emissions or reduce their growth rate; however, an energy system is needed. On the other hand, any change in fuel or energy infrastructure requires a very long transition time. Long. Even oil exploration projects take a long time to complete (a decade) [11]. Hybrid vehicles have been sold to the public for five years, and even in 2019, they only make up $2.5 \%$ of all cars 
sold. Any large-scale energy transition will inevitably take a long time. The important thing is to plan the transition carefully to obtain the desired result [17].

To stabilize the concentration of $\mathrm{CO}_{2}$ in the atmosphere (and therefore the global climate), it is necessary to reduce global $\mathrm{CO}_{2}$ emissions to approximately 3 billion tons per year, equivalent to a third of current emissions and a sixth of the emissions projected for the year 2050 [27]. This is equivalent to less than one ton of $\mathrm{CO}_{2}$ per person per year. To put this in perspective, a ton of $\mathrm{CO}_{2}$ is generated by watching television or using a personal computer 8 hours a day for a year, driving $50 \mathrm{~km}$ a day in a high-efficiency vehicle (40 km/liter) for a year, or traveling $6000 \mathrm{~km}$ on a commercial flight. Efficiency improvements alone will not reduce $\mathrm{CO}_{2}$ emissions to the level required to stabilize the global climate. It is necessary to transform energy systems so that they do not produce $\mathrm{CO}_{2[41]}$.

It is possible to estimate the time available to reduce $\mathrm{CO}_{2}$ emissions by combining a climatological model with projections on energy demand. Suppose we assume that the global temperature will increase by $3^{\circ} \mathrm{C}$ as a consequence of a doubling of the $\mathrm{CO}_{2}$ concentration in the atmosphere (this is the intermediate case of climate sensitivity assumed by the International Conference on Climate Change). In that case, it will require that $80 \%$ of the energy be produced without generating $\mathrm{CO}_{2}$ by 2050 if global warming is limited to $2^{\circ} \mathrm{C}[18]$. Currently, $80 \%$ of energy is produced from fossil fuels.

In short, the transition to hydrogen will take several decades. However, the long period required ( 50 years) means starting immediately [33]. Delaying the transition increases the concentration of $\mathrm{CO}_{2}$ in the atmosphere, increasing our vulnerability to future climate change. The first step is to increase energy efficiency. This will allow time to develop an energy system that does not emit $\mathrm{CO}_{2}$ and is economical and at the place of use[52].

Viable. By the middle of this century, stabilizing the climate requires that hydrogen technologies mature considerably and be implemented globally [17]. Hydrogen is the only fuel that can be clean, carbon-free, universally applicable to all modes of transport, and producible on the scale necessary to meet everyone's needs (Figure 166). The hydrogen economy is necessary for the future [13].

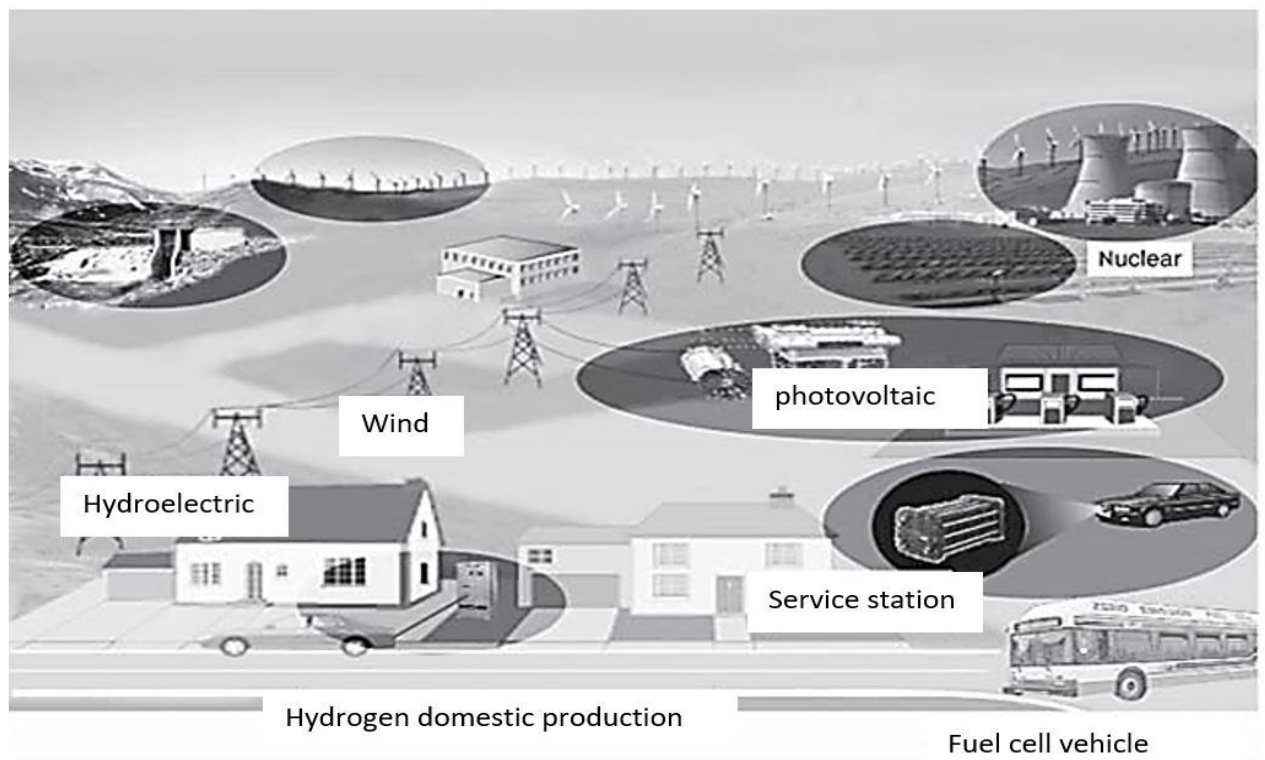

Figure 16. Energy system based on renewable and nuclear energy with electrolytic hydrogen generation[1-10]

3.1.4 Hydrogen technologies are not ready for large-scale implementation 
We agree that the technologies required for the hydrogen economy are not mature enough for commercial use globally. The hydrogen economy requires mass-produced components with low costs and high levels of safety[7]. New technologies don't need to be invented, but future technological advancements can make hydrogen vehicles much more useful to users and more attractive to investors[9].

The hydrogen economy will be very different from the flexible infrastructure that can adapt to scientific discoveries, technological advances, structural changes in the economy, and societal attitudes [16].

Of all the technologies required for the hydrogen economy, production technologies are the most mature. Since hydrogen was discovered as a water component more than 200 years ago, hydrogen has been produced from water using fossil fuels or electricity. The most common method is methane reformation. This method is relatively efficient in terms of capital and energy (60\% - 70\%) [25], and it is an appropriate process to produce today's economy due to the requirements and opportunities that arise when trying to produce, store and use hydrogen. Hydrogen is likely humanity's last chemical fuel. Therefore, it is necessary to generate one of its use (for example, in an oil refinery or an ammonia production plant). The economic advantage of reforming diminishes if hydrogen has to be delivered to filling stations, especially in the initial stages of the transition to hydrogen when the demand for hydrogen is too small to justify a pipeline to transport hydrogen[19].

Hydrogen can also be produced on a small scale at the place of use (in service stations by reforming or in private homes by electrolysis). However, hydrogen production technology on these small scales needs to be further developed to expand its economic value and safety[10].

Compared to hydrogen production, distribution, and storage, they are just maturing. Although hydrogen gas pipelines are in service, hydrogen is typically delivered by trucks that transport hydrogen in a gaseous state under high pressure or a liquid state [1, 45]. However, the metal tanks normally used to distribute compressed hydrogen are very heavy, limiting the amount of hydrogen transported and increasing distribution costs. Tanks for transporting liquid hydrogen are lighter because they operate at low pressures (110 atmospheres). Thus, a liquid hydrogen truck can carry 10 times more hydrogen than a compressed gas truck[55].

Unfortunately, it takes a lot of energy to liquefy hydrogen, requiring between $30 \%$ and $40 \%$ of its lower calorific value. Another problem is that liquid hydrogen tends to evaporate rapidly due to heat transfer from the environment[37].

Technologies for storing hydrogen in cars are even less mature, even though they are more important to hydrogen vehicles' commercial success [5]. Hydrogen's low energy density presents multiple challenges, especially compared to the very dense liquid hydrocarbons in use today[16].

The experience with liquid hydrogen comes mainly from the space program. Liquid hydrogen can easily be used in airplanes, ships, and trains, but these applications have little experience. Recently, several cars that run on liquid hydrogen have been built[66].

In cars, liquid hydrogen storage has come a long way in the last 30 years, mainly due to BMW's work [19]. In 2003, BMW built 15 liquid hydrogen cars that were subjected to extensive testing. The main challenge is keeping the liquid hydrogen at 20 kelvin for weeks [27]. Even vacuum insulation with multiple layers of reflective material is insufficient to reduce heat transfer to the tank to the level of $1 \mathrm{watt}$, which is necessary to avoid evaporative losses for 3-4 days in low-pressure tanks ( $\sim 7$ atmospheres). Higher pressure tanks can considerably reduce evaporation losses, recently demonstrated onboard a truck[18].

Many companies use high-pressure tanks to store compressed hydrogen in vehicles due to their higher degree of maturity. Compressed gas tanks have become increasingly practical because the fibers' resistance has made it possible to use very high-pressure tanks (700 atmospheres) [27]. 
Regardless of which technology is used in hydrogen vehicles, their range will be limited due to the low energy density of hydrogen [29]. Even in a liquid state, the energy density of hydrogen is only a quarter of gasoline. This large difference requires hydrogen vehicles to be very efficient $(30-40 \mathrm{~km} / \mathrm{L})$ to obtain a reasonable range $(\sim 500 \mathrm{~km})$ with one tank of fuel [33]. The required efficiency can be obtained with hybrid vehicles, although even higher efficiencies can be obtained with fuel cells. Fuel cell technology has come a long way in the last five years, but it can still be concluded that fuel cells, especially vehicles, are the least mature technology among all hydrogen storage, production and utilization technologies [18].

\subsection{Future of hydrogen economy}

The hydrogen economy's shape will take over the next 50 years depends on both known and unknown factors. However, it is possible to outline its main characteristics[55]. At least four models exist, depending on whether 1) hydrogen is produced from fossil fuels or from energy sources that do not generate $\mathrm{CO}_{2}$, and 2) whether hydrogen is produced on a small scale at the point of use or on a large scale at a central station and from there it is distributed[19].

\subsubsection{Large-scale nuclear hydrogen production}

This is the model proposed at the beginning of the 1970s [1,9]. Many nuclear plants were planned to be built, and oil and natural gas were cheap. Many countries were rapidly becoming electrified, and new power lines were obstacles to economic development[5]. One solution to this problem was to produce hydrogen in distant nuclear plants and transport the hydrogen in gas pipelines at a lower price than the cost of power lines, reducing the environmental pollution produced by fossil fuels[17]. Conditions have changed a lot in the last 30 years. In these years, public acceptance of nuclear energy and confidence in the techniques for storing radioactive waste have been considerably reduced[15]. In addition to that, solar and wind energy have become considerably cheaper, and both represent a new alternative to produce electricity without generating $\mathrm{CO}_{2}$. Nuclear power does not produce $\mathrm{CO}_{2}$ and is reliable and inexpensive, and therefore can be very useful in the future hydrogen economy[15]. Nuclear hydrogen production generates synergies with industrial operations, such as ammonia production to produce fertilizers or hydrogen liquefaction in large quantities. For example, a nuclear plant could be built nearby to produce the huge amount of liquid hydrogen needed in a large airport once all the planes use hydrogen as fuel (approximately $10,000 \mathrm{~kg}$ of liquid hydrogen per minute, equivalent to $20 \mathrm{GW}$ )[32] From the airport. Thus, energy could be easily distributed without the need for gas pipelines or power lines. Gas-cooled high-temperature nuclear reactors (currently under development) are suitable for liquid hydrogen production employing high-temperature electrolysis or thermochemical cycles[43].

\subsubsection{Centralized hydrogen production from fossil fuels with the capture of the $\mathrm{CO}_{2}$ produced}

It isn't easy to envision a hydrogen economy based on fossil fuels, but this may become the model of choice if it can be shown that technologies for capturing and storing underground $\mathrm{CO}_{2}$ are viable. In this model, coal would be the main source of hydrogen in the future due to its relative abundance and its low price compared to natural gas and oil[51, 62]. Coal can be used more efficiently to produce hydrogen than electricity, especially if $\mathrm{CO}_{2}$ must be captured and stored. It would be more appropriate to use nuclear or renewable energy to produce electricity, considering that electricity produced from coal can be expensive if the cost of capturing and geological storage of $\mathrm{CO}_{2}$ is included [23]. It is interesting to note that the fossil hydrogen model is similar to the nuclear hydrogen model. The hydrogen by gas pipeline distribution is probably more economical than the transmission of electricity generated in coal plants[30]. It is important to determine if the 
hydrogen produced is more valuable as a fuel for transportation or for generating electricity on a small scale in houses and buildings with stationary fuel cells. There is the possibility of recovering and taking advantage of the heat generated (co-generation). Stationary fuel cells are used continuously, and therefore their high initial cost can be justified[1418].

The most important technology for the success of this model is the capture and geological storage of $\mathrm{CO}_{2}$. Without this technology, the fossil hydrogen economy will produce more $\mathrm{CO}_{2}$ than the current economy. Also, gas pipelines (for hydrogen and $\mathrm{CO}_{2}$ ) are very important in this model. It is important to check whether current pipelines can be used (or adapted) for hydrogen[45-50].

\subsubsection{Hydrogen from natural gas on a small scale}

In this model, natural gas is distributed using the existing infrastructure, eliminating the need to build new infrastructure. However, instead of burning natural gas to produce heat, natural gas is reformed to produce hydrogen, and the heat produced in reforming can be used to heat water or cook (co-generation). This process is much more efficient than the current process of burning natural gas directly[71]. Hydrogen represents two-thirds of the energy of a molecule of methane $\left(\mathrm{CH}_{4}\right)$. Efficient reforming of this natural gas to generate hydrogen, heat, and electricity reduces electricity and hydrogen costs and, at the same time, reduces $\mathrm{CO}_{2}$ emissions[67]. Variations in electricity demand allow for excess production of hydrogen, which can be used for automobiles. Another possibility is to connect parked cars to the electricity grid to generate electricity at times of high demand, reducing the need to build more power plants[1]. This model requires high-efficiency $(\sim 75 \%)$ fuel cells and reformers. Fuel cells avoid building new power lines and providing heat, saving gas that would otherwise be used to produce it. This high-efficiency level would allow an economic transition to reduce energy demand and total $\mathrm{CO}_{2}$ emissions[2]. This model's success depends on the reasonable cost of natural gas and the ability to manufacture fuel cells with high efficiency and durability[4-7]. There may be problems with this model in the medium term because natural gas deposits may deplete. Finally, this model works only during the transition period to hydrogen because natural gas generates $\mathrm{CO}_{2}$. In the long term, we need an energy system that does not produce $\mathrm{CO}_{2}$.

\subsubsection{Hydrogen from small-scale renewable energy}

This model has been described since the early 1970s [1-10], but it has become a real option in the last ten years because the cost of renewable energy has dropped considerably. In this model, the synergy between renewable energy and hydrogen intermittency can be exploited because hydrogen is much easier to store than electricity[7]. When solar or wind energy levels are high, excess electricity can generate hydrogen through electrolysis for direct use as fuel in cars or to produce electricity on windless days or in periods without sunlight on cloudy days or at night. This model is somewhat the inverse of the small-scale hydrogen model from natural gas. Instead of consuming hydrogen in fuel cells to produce electricity (and heat), electricity is consumed in electrolyzers to produce hydrogen (and heat)[56-67]. The biggest challenge for renewable hydrogen is the cost[44-70]. The cost of renewable electricity depends on the system's cost necessary to generate or distribute renewable energy. Synchronizing the daily, weekly and annual variations in production, consumption, and storage of electricity, hydrogen, and heat, both for buildings and vehicles, is a complex but necessary problem to obtain an economically efficient system[31]. The problem of timing is likely to become easier and easier with the development of information technology. Future energy markets should reflect (and respond to) sudden changes in the cost of energy services. The biggest advantage of being gained from a renewable energy system may be to allow consumers to intelligently evaluate their energy options in terms of quantity and quality, timing, intensity, and duration[72, 73]. 


\section{Conclusion}

The selected route of $\mathrm{H}_{2}$ production is dictated by the economics of the process, the market's needs, and environmental regulations. Hydrogen allows access to a wide group of primary precursors such as fossil fuels, nuclear energy, and increasing penetration and renewable energies (wind, solar, biomass). The cost of hydrogen as a non-polluting energy carrier will be more stable through all these alternatives than any other source. The introduction of hydrogen and electricity as energy carriers will make it possible to exploit indigenous resources and thus reduce the heavy dependence on oil.

The hydrogen economy provides multiple benefits, including clean air and energy independence. However, the most important benefit is the stabilization of the global climate. Hydrogen is the most economical means of reducing $\mathrm{CO}_{2}$ emissions considerably $(80 \%-90 \%)$ to the levels necessary to avoid putting climate stability at risk. This makes the conversion to hydrogen an urgent necessity. Hydrogen is the only fuel produced on the scale necessary to be used globally in all modes of transportation. In the long term, hydrogen allows solar, wind, and nuclear energy to replace the fossil energy used in electricity generation and transportation, efficiently taking advantage of natural variations in power generated in solar or wind energy systems.

The production and storage of hydrogen involve additional energy (and therefore economic) expenditure, but this expenditure can be offset by efficient use and co-generation of electricity and heat. Although it is unnecessary to invent new technologies for the hydrogen economy, it is necessary to develop existing technologies to be used by the general public. Advances in the electrochemistry of electrolyzers and fuel cells and improvements to high pressure and cryogenic tanks will considerably improve the future hydrogen economy's characteristics. Hydrogen production can be centralized or decentralized, based on fossil fuels or renewable or nuclear energy. The production characteristics determine the need to develop new infrastructures, such as gas pipelines, power lines, tankers, and service stations. If geological storage of $\mathrm{CO}_{2}$ is practical on a large scale, hydrogen can be generated from coal to replace fossil fuels, although an extensive hydrogen distribution infrastructure would need to be built. If the geological storage problems of $\mathrm{CO}_{2}$ cannot be solved, it will be necessary to make an effort to increase the efficiency of current energy systems and prepare for the transition to renewable hydrogen as we learn more about climate change, the availability of fossil fuels. And future energy demand. The fundamental question about the hydrogen economy is not when it will happen but when. The transition from the fossil economy to the hydrogen economy will take one to two decades (just like all previous transitions). Considering that the hydrogen economy is necessary to stabilize the climate, we have no choice but to work enthusiastically to make it a reality.

\section{References}

[1] The European Parliament; Council of the European Union. 2018/842 of the European Parliament and of the Council of 30 May 2018 on binding annual greenhouse gas emission reductions by Member States from 2021 to 2030 contributing to climate action to meet commitments under the Paris Agreement and amending Regulation (EU) No 525/2013. Off. J. Eur. Union 2018, 156, 2642.

[2] Gnann, T.; Plötz, P. A review of combined models for market diffusion of alternative fuel vehicles and their refueling infrastructure. Renew. Sustain. Energy Rev. 2015, 47, 783-793.

[3] Robinius, M.; Otto, A.; Syranidis, K.; Ryberg, D.S.; Heuser, P.; Welder, L.; Grube, T.; Markewitz, P.; Tietze, V.; Stolten, D. Linking the Power and Transport Sectors - Part 2: Modelling a Sector Coupling Scenario for Germany. Energies 2017, $10,957$.

[4] Fuel Cells and Hydrogen Joint Untertaking (FCH JU). FCH JU Projects. Available online: https://www.fch.europa.eu/fchju-projects (accessed on 18 March 2019).

[5] Wulf, C.; Linßen, J.; Zapp, P. Review of Power-to-Gas Projects in Europe. Energy Procedia 2018, 155, $367-378$.

[6] Almansoori, A.; Shah, N. Design and operation of a future hydrogen supply chain: Multi-period model. Int. J. Hydrogen Energy 2009, 34, 7883-7897.

[7] Hugo, A.; Rutter, P.; Pistikopoulos, S.; Amorelli, A.; Zoia, G. Hydrogen infrastructure strategic planning using multi-objective optimization. Int. J. Hydrogen Energy 2005, 30, 1523-1534. 
[8] Nunes, P.; Oliveira, F.; Hamacher, S.; Almansoori, A. Design of a hydrogen supply chain with uncertainty. Int. J. Hydrogen Energy 2015, 40, 16408-16418.

[9] Agnolucci, P.; Akgul, O.; McDowall, W.; Papageorgiou, L.G. The importance of economies of scale, transport costs and demand patterns in optimising hydrogen fuelling infrastructure: An exploration with SHIPMod (Spatial hydrogen infrastructure planning model). Int. J. Hydrogen Energy 2013, 38, 11189-11201.

[10] Sabio, N.; Gadalla, M.; Guillén-Gosálbez, G.; Jiménez, L. Strategic planning with risk control of hydrogen supply chains for vehicle use under uncertainty in operating costs: A case study of Spain. Int. J. Hydrogen Energy 2010, 35, 6836-6852.

[11] Konda, N.M.; Shah, N.; Brandon, N.P. Optimal transition towards a large-scale hydrogen infrastructure for the transport sector: The case for the Netherlands. Int. J. Hydrogen Energy 2011, 36, 4619-4635.

[12] Kim, M.; Kim, J. Optimization model for the design and analysis of an integrated renewable hydrogen supply (IRHS) system: Application to Korea's hydrogen economy. Int. J. Hydrogen Energy 2016, 41, 16613-16626.

[13] Han, J.-H.; Ryu, J.-H.; Lee, I.-B. Modeling the operation of hydrogen supply networks considering facility location. Int. J. Hydrogen Energy 2012, 37, 5328-5346.

[14] Stiller, C.; Bünger, U.; Møller-Holst, S.; Svensson, A.M.; Espegren, K.A.; Nowak, M. Pathways to a hydrogen fuel infrastructure in Norway. Int. J. Hydrogen Energy 2010, 35, 2597-2601.

[15] Li, Z.; Gao, D.; Chang, L.; Liu, P.; Pistikopoulos, E.N. Hydrogen infrastructure design and optimization: A case study of China. Int. J. Hydrogen Energy 2008, 33, 5275-5286.

[16] Hwangbo, S.; Lee, I.-B.; Han, J. Mathematical model to optimize design of integrated utility supply network and future global hydrogen supply network under demand uncertainty. Appl. Energy 2017, 195, 257-267.

[17] De-León Almaraz, S.; Azzaro-Pantel, C.; Montastruc, L.; Boix, M. Deployment of a hydrogen supply chain by multi-objective/multi-period optimisation at regional and national scales. Chem. Eng. Res. Des. 2015, 104, 11-31.

[18] Moreno-Benito, M.; Agnolucci, P.; Papageorgiou, L.G. Towards a sustainable hydrogen economy: Optimisation-based framework for hydrogen infrastructure development. Comput. Chem. Eng. 2017, 102, 110-127.

[19] Dayhim, M.; Jafari, M.A.; Mazurek, M. Planning sustainable hydrogen supply chain infrastructure with uncertain demand. Int. J. Hydrogen Energy 2014, 39, 6789-6801.

[20] Yang, C.; Ogden, J.M. Renewable and low carbon hydrogen for California e Modeling the long term evolution of fuel infrastructure using a quasi-spatial TIMES model. Int. J. Hydrogen Energy 2013, 38, 4250-4265.

[21] Kim, M.; Kim, J. An integrated decision support model for design and operation of a wind-based hydrogen supply system. Int. J. Hydrogen Energy 2017, 42, 3899-3915.

[22] Welder, L.; Ryberg, D.S.; Kotzur, L.; Grube, T.; Robinius, M.; Stolten, D. Spatio-temporal optimization of a future energy system for power-to-hydrogen applications in Germany. Energy 2018, 158, 1130-1149.

[23] Stephens-Romero, S.D.; Brown, T.M.; Kang, J.E.; Recker, W.W.; Samuelsen, G.S. Systematic planning to optimize investments in hydrogen infrastructure deployment. Int. J. Hydrogen Energy 2010, 35, 4652-4667.

[24] Kuby, M.; Lines, L.; Schultz, R.; Xie, Z.; Kim, J.-G.; Lim, S. Optimization of hydrogen stations in Florida using the Flow-Refueling Location Model. Int. J. Hydrogen Energy 2009, 34, 6045-6064.

[25] He, C.; Sun, H.; Xu, Y.; Lv, S. Hydrogen refueling station siting of expressway based on the optimization of hydrogen life cycle cost. Int. J. Hydrogen Energy 2017, 42, 16313-16324.

[26] Li, L.; Manier, H.; Manier, M.A. Hydrogen supply chain network design: An optimization-oriented review. Renew. Sustain. Energy Rev. 2019, 103, 342-360.

[27] Heuberger, C.F.; Rubin, E.S.; Staffell, I.; Shah, N.; Mac Dowell, N. Power capacity expansion planning considering endogenous technology cost learning. Appl. Energy 2017, 204, 831-845.

[28] Kohler, J.; Grubb, M.; Popp, D.; Edenhofer, O. The transition to endogenous technical change in climate-economy models: A technical overview to the Innovation Modeling Comparison Project. Energy J. 2006, 27, 17-55.

[29] Kahouli-Brahmi, S. Technological learning in energy-environment-economy modelling: A survey. Energy Policy 2008, 36, 138162.

[30] Bolat, P.; Thiel, C. Hydrogen supply chain architecture for bottom-up energy systems models. Part 1: Developing pathways. Int. J. Hydrogen Energy 2014, 39, 8881-8897.

[31] Nistor, S.; Dave, S.; Fan, Z.; Sooriyabandara, M. Technical and economic analysis of hydrogen refuelling. Appl. Energy 2016, 167, 211-220.

[32] Yang, C.; Odgen, JM Determining the lowest-cost hydrogen delivery mode. Int. J. Hydrogen Energy 2007, 32, 268-286.

[33] Reuß, M.; Grube, T.; Robinius, M.; Preuster, P.; Wasserscheid, P.; Stolten, D. Seasonal storage and alternative carriers: A flexible hydrogen supply chain model. Appl. Energy 2017, 200, 290-302.

[34] Grüger, F.; Hoch, O.; Hartmann, J.; Robinius, M.; Stolten, D. Optimized electrolyzer operation: Employing forecasts of wind energy availability, hydrogen demand, and electricity prices. Int. J. Hydrogen Energy 2019, 44, 4387-4397.

[35] Krieg, D. Konzept und Kosten Eines Pipelinesystems zur Versorgung des Deutschen Straßenverkehrs mit Wasserstoff; Forschungszentrum Jülich: Jülich, Germany, 2012; p. 22.

[36] Tzimas, E.; Castello, P.; Peteves, S. The evolution of size and cost of a hydrogen delivery infrastructure in Europe in the medium and long term. Int. J. Hydrogen Energy 2007, 32, 1369-1380. 
[37] Qadrdan, M.; Saboohi, Y.; Shayegan, J. A model for investigation of optimal hydrogen pathway, and evaluation of environmental impacts of hydrogen supply system. Int. J. Hydrogen Energy 2008, 33, 7314-7325.

[38] Shafiei, E.; Davidsdottir, B.; Leaver, J.; Stefansson, H.; Asgeirsson, E.I. Energy, economic, and mitigation cost implications of transition toward a carbon-neutral transport sector: A simulation-based comparison between hydrogen and electricity. J. Clean. Prod. 2017, 141, 237-247.

[39] Brey, J.J.; Carazo, AF; Brey, R. Analysis of a hydrogen station roll-out strategy to introduce hydrogen vehicles in Andalusia. Int. J. Hydrogen Energy 2014, 39, 4123-4130.

[40] Almansoori, A.; Shah, N. Design and operation of a stochastic hydrogen supply chain network under demand uncertainty. Int. J. Hydrogen Energy 2012, 37, 3965-3977.

[41] Heinz, B.; Graeber, M.; Praktiknjo, A.J. The diffusion process of stationary fuel cells in a two-sided market economy. Energy Policy 2013, 61, 1556-1567.

[42] Meade, N. The use of growth curves in forecasting market development-A review and appraisal. J. Forecast. $1984,3,429-451$.

[43] Adner, R.; Kapoor, R. Innovation ecosystems and the pace of substitution: Re-examining technology S-curves. Strateg. Manag. J. 2016, 37, 625-648.

[44] Bass, F. A new product growth for model consumer durables. Manag. Sci. 1969, 15, 215-227.

[45] Bass, F.M.; Krishnan, T.V.; Jain, D.C. Why the Bass model fits without decision variables. Mark. Sci. 1994, 3, $203-223$.

[46] Park, S.Y.; Kim, J.W.; Lee, H.D. Development of a market penetration forecasting model for Hydrogen Fuel Cell Vehicles considering infrastructure and cost reduction effects. Energy Policy 2011, 39, 3307-3315.

[47] Kim, T.; Hong, J. Bass model with integration constant and its applications on initial demand and left-truncated data. Technol. Forecast. Soc. Chang. 2015, 95, 120-134.

[48] Gagniuc, P.A. Markov Chains: From Theory to Implementation and Experimentation; John Wiley \& Sons: Hoboken, NJ, USA, 2017.

[49] Tran, M.; Banister, D.; Bishop, J.D.K.; McCulloch, M.D. Simulating early adoption of alternative fuel vehicles for sustainability. Technol. Forecast. Soc. Chang. 2013, 80, 865-875.

[50] Lee, H.; Kim, S.G.; Park, H.W.; Kang, P. Pre-launch new product demand forecasting using the Bass model: A statistical and machine learning-based approach. Technol. Forecast. Soc. Chang. 2014, 86, 49-64.

[51] Benvenutti, L.M.M.; Ribeiro, A.B.; Uriona, M. Long term diffusion dynamics of alternative fuel vehicles in Brazil. J. Clean. Prod. 2017, 164, 1571-1585.

[52] Joest, S.; Fichtner, M.; Wietschel, M.; Bünger, U.; Stiller, C.; Schmidt, P.; Merten, F. GermanHy: Studie zur Frage: “Woher kommt der Wasserstoff in Deutschland bis 2050?"; Studie im Auftrag des BMBF: Berlin, Germany, 2009.

[53] Nitsch, J.; Pregger, T.; Naegler, T.; Heide, D.; de Tena, D.L.; Trieb, F.; Scholz, Y.; Nienhaus, K.; Gerhardt, N.; Sterner, M. Langfristszenarien und Strategien für den Ausbau der Erneuerbaren Energien in Deutschland bei Berücksichtigung der Entwicklung in Europa und Global, Deutsches Zentrum für Luft-und Raumfahrt, Fraunhofer Institut für Windenergie und Energiesystemtechnik; Ingenieurbüro für neue Energien: Teltow, Germany, 2012.

[54] Adolf, J.; Lischke, A.; Knitschky, G. Perspektiven für neue Antriebe und Kraftstoffe von Nutzfahrzeugen. Int. Verk. 2016, 68, 8285.

[55] Lenz, B.; Lischke, A.; Knitschky, G.; Adolf, J.; Balzer, C.; Haase, F. Shell Nutzfahrzeug-Studie Diesel oder Alternative AntriebeWomit Fahren Lkw und Bus Morgen; Deutsches Zentrum für Luft- und Raumfahrt (DLR): Cologne, Germany, 2016.

[56] Berger, R. Fuel Cell Electric Buses-Potential for Sustainable Public Transport in Europe; Fuel Cells and Hydrogen Joint Undertaking (FCHJU): Brussels, Belgium, 2015.

[57] Ziegler, C. Wasserstoff-Triebzug Coradia iLint in der Testphase. Available online: https://www.internationales-verkehrswesen.de/wasserstoff-triebzug-coradia-ilint-test/ (accessed on 21 April 2018).

[58] Ritter, M. Wasserstoff und Brennstoffzelle im Schienenverkehr; ALSTOM: Saint-Ouen, France, 2016.

[59] Posdziech, N. 14 Brennstoffzellen-Züge für Niedersachsen; NOW GmbH: Berlin, Germany, 2017.

[60] Castello, P.; Tzimas, E.; Moretto, P.; Peteves, S. Techno-Economic Assessment of Hydrogen Transmission \& Distribution Systems in Europe in the Medium and Long Term; Joint Research Center (JRC): Brussels, Belgium, 2005.

[61] Albrecht, U.; Bünger, U.; Michalski, J.; Weindorf, W.; Zerhausen, J.; Borggrefe, F.; Gils, H.; Pregger, T.; Kleiner, F.; Pagenkopf, J.; et al. Kommerzialisierung der Wasserstofftechbnologie in Baden-Württemberg; Landesagentur für elektromobilität und Brennstoffzellentechnologie ind Baden-Württemberg GmbH: Stuttgart, Germany, 2016.

[62] Coradia iLint Regional Train. Available online: http://www.alstom.com/products-services/product-catalogue/rail-systems/trains/products/coradia-ilint-regional-train-/] (accessed on 11 December 2017).

[63] Grünwald, R. Perspektiven eines CO2-und Emissionsarmen Verkehrs-Kraftstoffe und Antriebe im Überblick; Büro für Technikfolgenabschätzung des Deutschen Bundestages: Zürich, Schweiz, 2006.

[64] Kirchner, A.; Matthes, F.; Ziesing, H. Modell Deutschland Klimaschutz bis 2050: Vom Ziel her Denken; Institute for Applied Ecology: Corvallis, OR, USA, 2009.

[65] Lischke, A.; Bünger, U.; Landinger, H.; Pschorr-Schoberer, E.; Schmidt, P.; Weindorf, W.; Jöhrens, J.; Lambrecht, U.; Naumann, K. Power-to-Gas (PtG) in Transport Status quo and Perspectives for Development; Deutsches Zentrum für Luft- und Raumfahrt e.V. (DLR): Cologne, Germany, 2014. 
[66] Summerton, P. Low-Carbon Cars in Germany: Technical Report, Cambridge Econometrics; Element Energy: Cambridge, UK, 2017.

[67] Adolf, J.; Balzer, C.; Joedicke, A.; Schabla, U.; Wilbrand, K.; Rommerskirchen, S.; Anders, N.; Auf der Maur, A.; Ehrentraut, O.; Krämer, L.; et al. Shell PKW-Szenarien bis 2040; Shell Deutschland Oil GmbH: Hamburg, Germany, 2016.

[68] European Commission. EUR 23123-HyWays the European Hydrogen Roadmap; European Commission: Brussels, Belgium, 2017.

[69] Robinius, M.; Linßen, J.; Grube, T.; Reuß, M.; Stenzel, P.; Syranidis, K.; Kuckertz, P.; Stolten, D. Comparative Analysis of Infrastructures: Hydrogen Fueling and Electric Charging of Vehicles; Forschungszentrum Jülich: Jülich, Germany, 2018.

[70] Fraile, D.; Torres, A.; Rangel, A.; Barth, F.; Lanoix, J.-C.; Vanhoudt, W. Generic Estimation Scenarios of Market Penetration and Demand Forecast for "Premium" Green Hydrogen in Short, Mid and Long Term. Available online: https://www.certifhy.eu/images/project/reports/D1_3_Hydrogen_Market_Outlook_Final_-_V2.pdf (accessed on 16 May 2016).

[71] Hydrogen Council. Hydrogen Scaling up: A Sustainable Pathway for the Global Energy Transition; Hydrogen Council: Brussels, Belgium, 2017.

[72] ChemCoast. Fahrplan zur Realisierung einer Windwasserstoff-Wirtschaft in der Region Unterelbe; ChemCoast: La Porte, TX, USA, 2016.

[73] Repenning, J.; Emele, L.; Blanck, R.; Böttcher, H.; Dehoust, G.; Förster, H.; Greiner, B.; Harthan, R.; Henneberg, K.; Hermann, H.; et al. Klimaschutzszenario 2050; Fraunhofer ISI, Öko-Institut: Berlin, Germany, 2015. 